\title{
Investigating the Factors Affecting the Professional Commitment of Accounting Students Using an Anticipatory Socialization Model
}

\author{
Fahime Ebrahimi* \\ Assistant Professor of Accounting, Jahrom University, Jahrom, Iran \\ (Corresponding Author), febrahimi@jahromu.ac.ir \\ Reza Taghizadeh \\ Assistant Professor of Accounting, Yazd University, Yazd, Iran \\ (rezataghizadeh@yazd.ac.ir) \\ Amin Rostami \\ Assistant Professor of Accounting, Isfahan University, Isfahan, Iran \\ (a.rostami@ase.ui.ac.ir)
}

\begin{abstract}
:
The purpose of this study is to investigate the factors affecting the professional commitment of accounting students as a result of the anticipatory socialization process and in the framework of the college impact model of input-environment-output. This study is a descriptive and correlational research and the statistical population of this study consists of accounting final year undergraduate students of public universities across the country. The information required for this study was collected by completing a questionnaire by 190 students in 2020 . In order to test the hypotheses, the partial least squares structural equation modelling has been used. The results of the study indicate a positive and significant effect of studentschr motivation and their involvement on professional commitment. The results also show a positive and significant effect of studentschr motivation on the perceived environment and their involvement. In addition, the results suggest that student involvement plays a mediating role in the relationship between motivation and professional commitment as well as in the relationship between perceived environment and professional commitment. The results of this study indicate that the inputenvironment-output model can provide a suitable framework for

Copyrights:

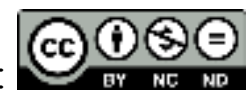

This license only allowing others to download your works and share them with others as long as they credit you, but they can't change them in any way or use them commercial.
\end{abstract}


examining the process of anticipatory socialization and explaining the factors affecting the professional commitment of accounting students, as the outcome of the anticipatory socialization process.

Keywords: Professional commitment, Anticipatory socialization, Input- environment-output model, Motivation, Involvement.

Copyrights:

This license only allowing others to download your works and share them with others as long as they credit you, but they can't change them in any way or use them commercial. 


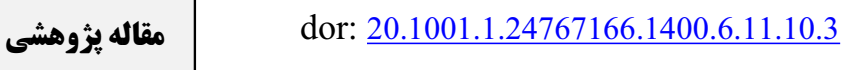

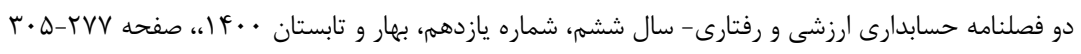

\section{بررسى عوامل مؤثر بر تعهد حرفهاى دانشجويان حسابدارى با استفاده از مدل جامعهيذيرى دانشكاهى}

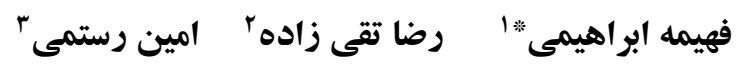

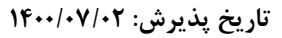

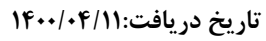

\section{جكيده}

هدف اين يثوهش بررسى عوامل مؤثر بر تعهد حرفهاى دانشجويان حسابدارى در نتيجه فرآيند

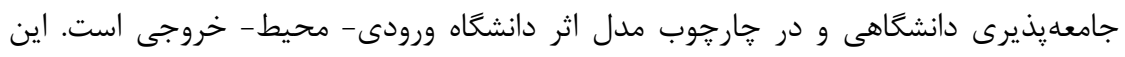

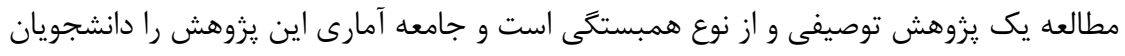
سال آخر مقطع كارشناسى دانشخاههاى دولتى سراسر كشور در رشته حسابدارى تشكيل مى دهند. اطلاعات مورد نياز اين يروهش از طريق تكميل : برسشنامه توسط • 19 نفر از دانشجويان

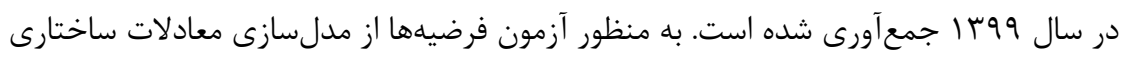
به روش كمترين مربعات جزئى استفاده شده است. نتايج حاصل از يزوهش بيانگر تأثير مثبت و معنادار انخيزه دانشجويان و مشاركت در فعاليتهاى علمى دانشخاهى آنها بر تعهد حرفهاى است.

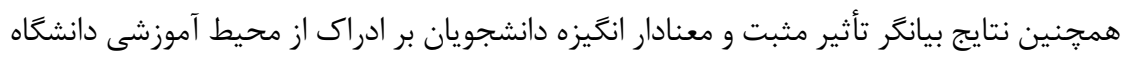

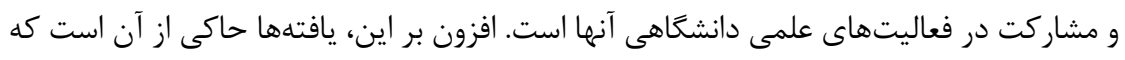

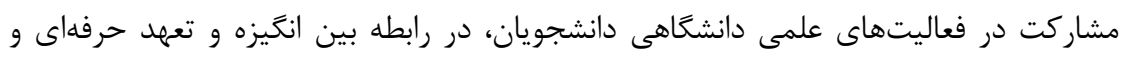

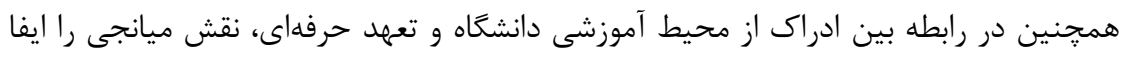
مى كند. نتايج اين :يزوهش بيانكر اين است كه مدل ورودى - محيط - خروجى مى تواند جار جوب

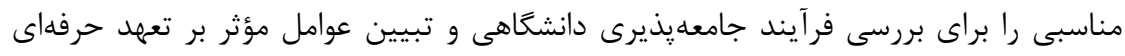

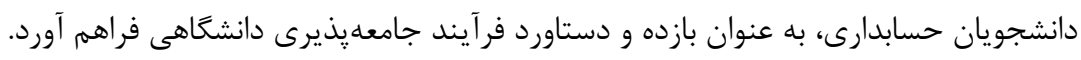
وازه هاى كليدى: تعهد حرفهاى، جامعهيذيرى دانشخاهى، مدل ورودى- محيط - خروجى، انخيزه، مشاركت در فعاليتهاى علمى دانشخاهى.

febrahimi@jahromu.ac.ir ، استاديار حسابدارى، دانشعاه جهرم، جهرم، ايران (نويسنده مسئول) rاستاديار حسابدارى، دانشعاه يزد، يزد، ايران (rezataghizadeh@yazd.ac.ir)

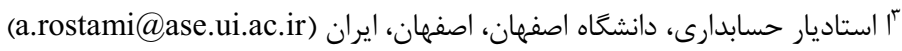


مباحث اخلاقى در حسابدارى طى ساليان اخير توجه زيادى را به خود جلب كرده است. يكى آغ إنى

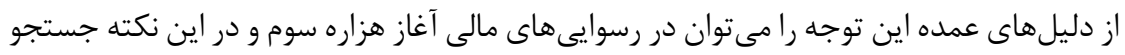

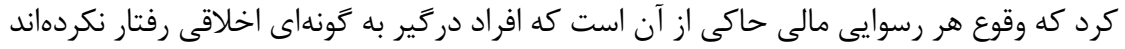

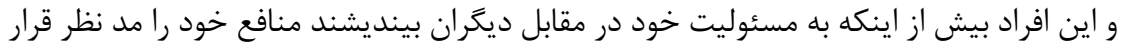

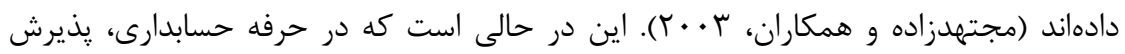

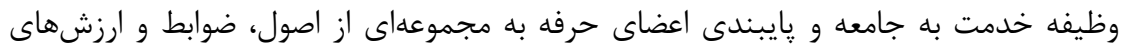

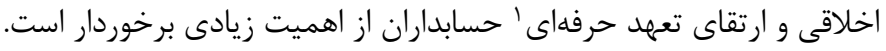

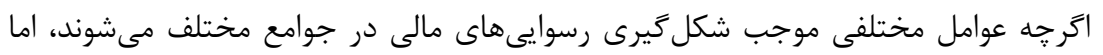

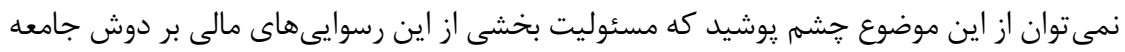

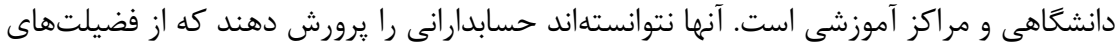

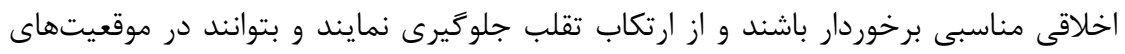

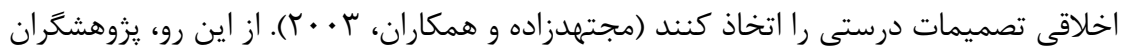

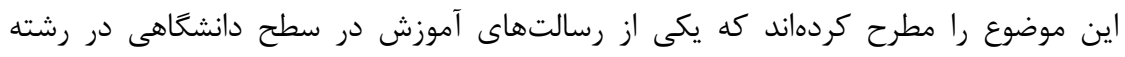

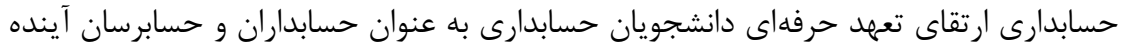

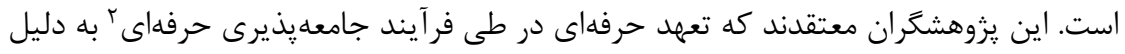

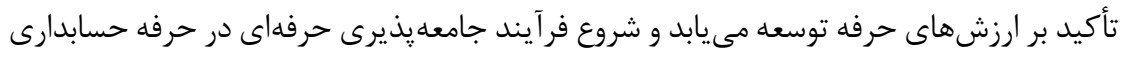

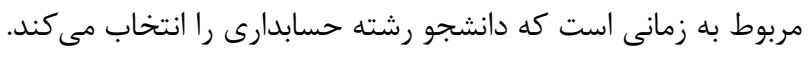

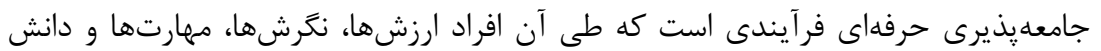

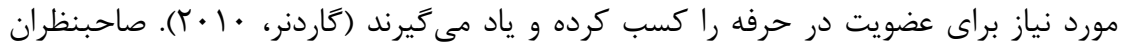

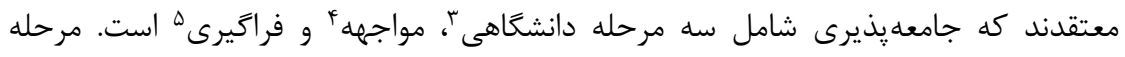

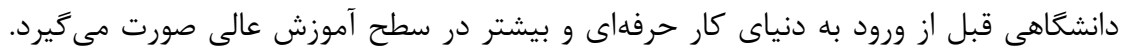

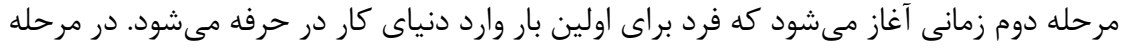

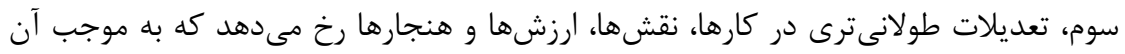

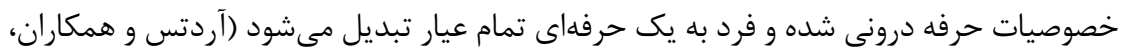

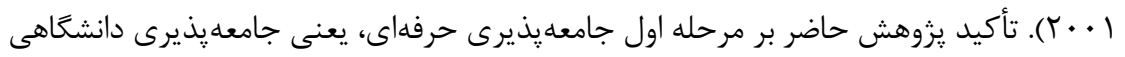

1. Professional commitment

2. Professional socialization

3 - Anticipatory phase

4- Encounter phase

5 - Acquisition phase 
و بر تعهد حرفهاى به عنوان دستاورد و پيامد جامعهيذيرى دانشخاهى است. هدف اين يزوهش

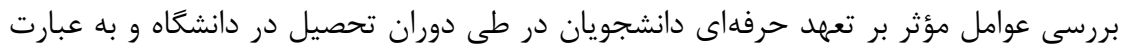

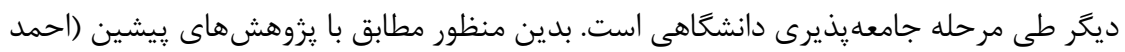

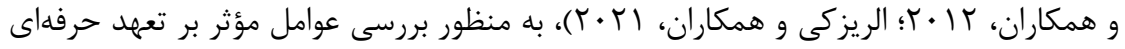

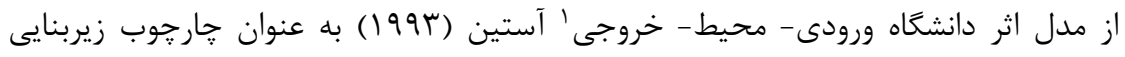
استفاده مىشود. نتايج يزوهشهاى بيشين بيانكر اهميت تعهد حرفهاى در حرفه حسابدارى است (يورتر و

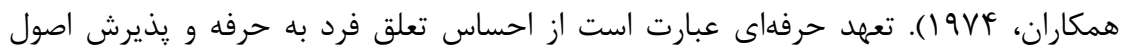

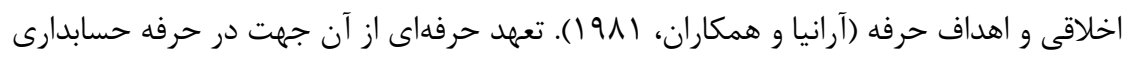

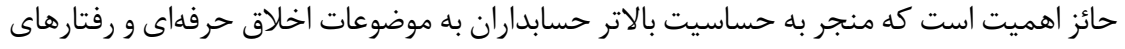

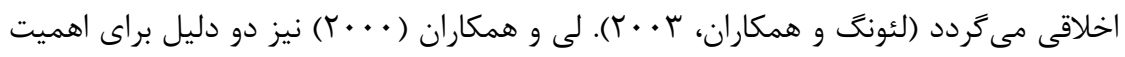

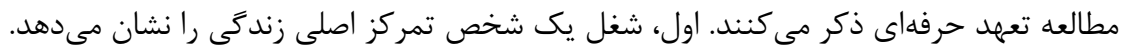
دوم، تعهد حرفهاى ييامدهاى مهمى در سطح فردى و سازمانى دارد. به عنوان مثال، نتايج يزولهش

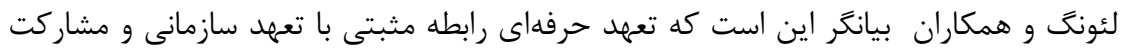

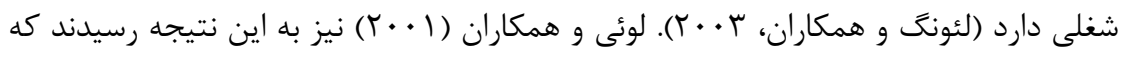

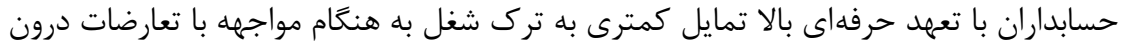

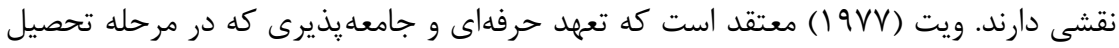

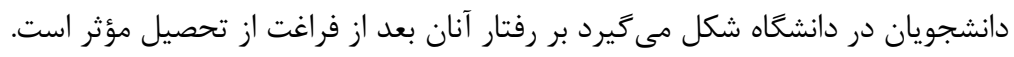

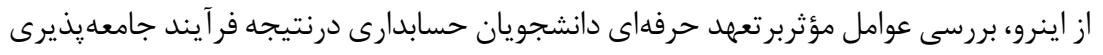

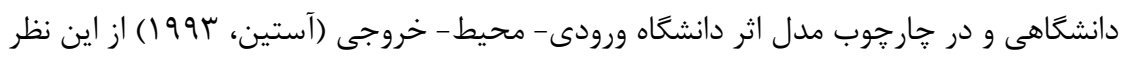

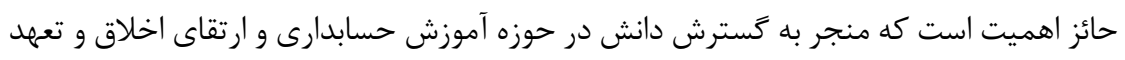

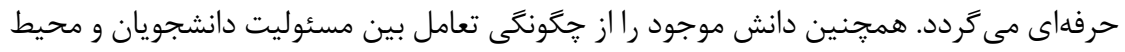

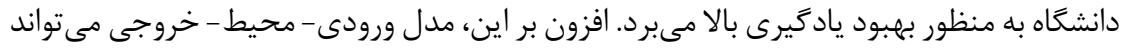

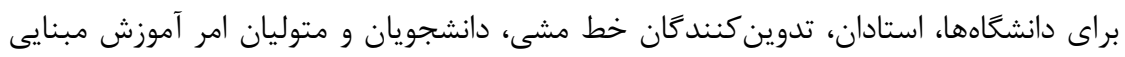

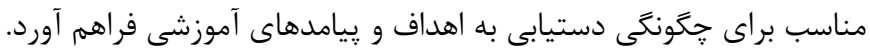

r- مبانى نظرى و پِيشينه يزوهش

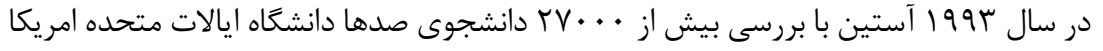

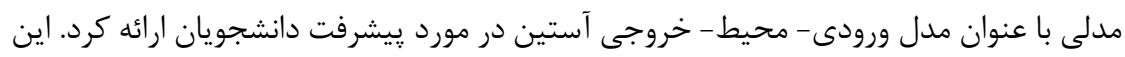

1. College impact model of input-environment-output 


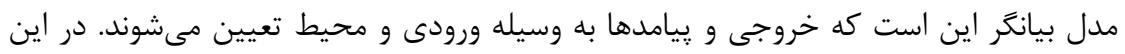

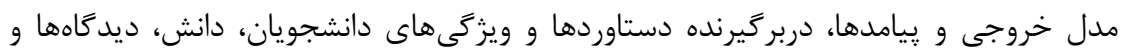

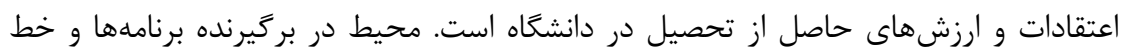

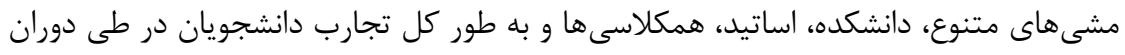

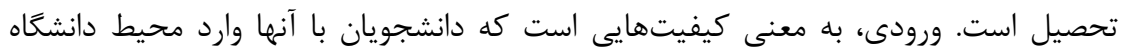

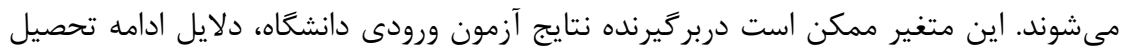

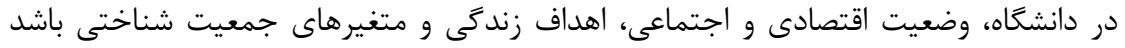

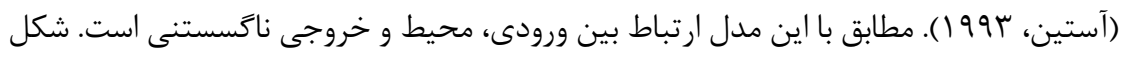

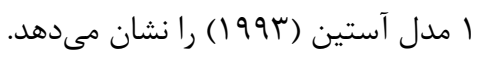

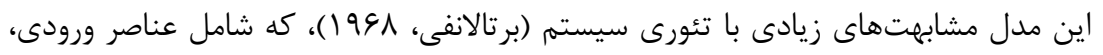

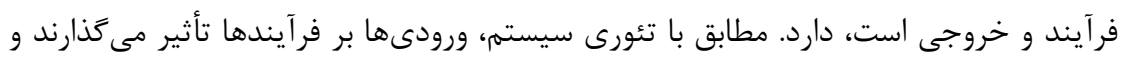

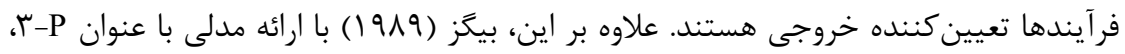

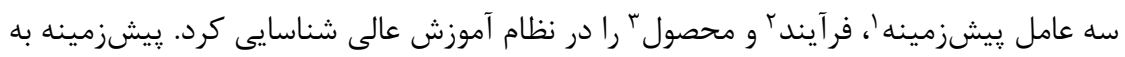

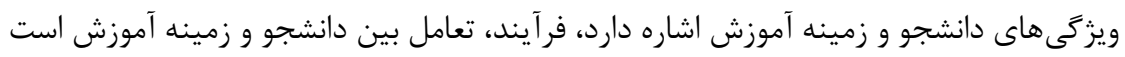

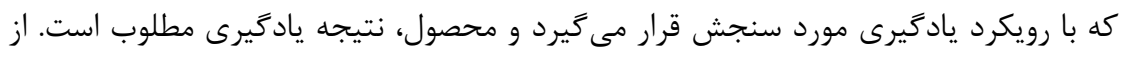

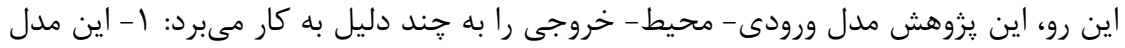

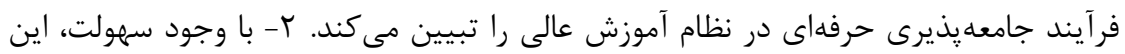

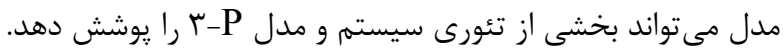

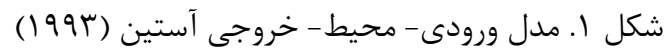

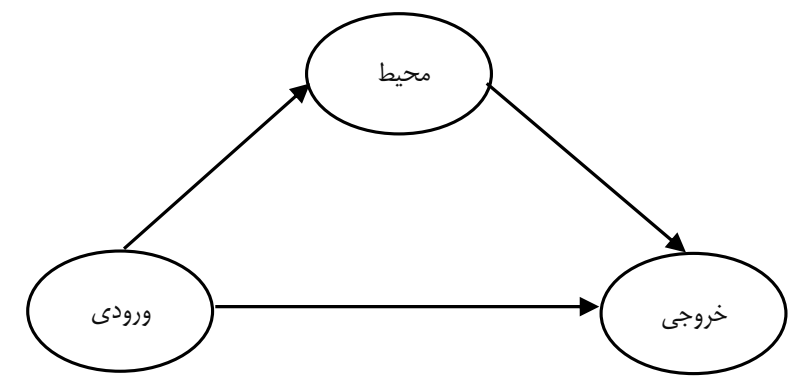

1 - Presage

2. Process

3. Product 
در ادامه به پِيشينه يزوهشهاى انجام شده مرتبط با اين حوزه يرداخته مىشود.

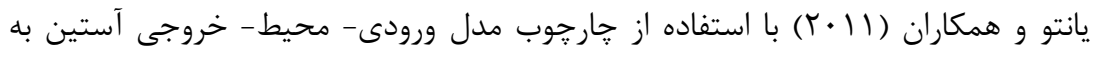

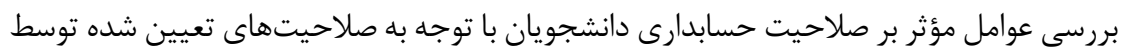

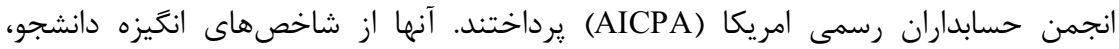

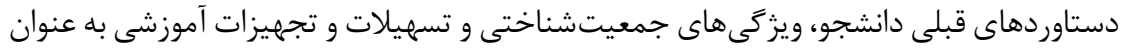
ورودى، مشاركت در فعاليتهاى علمى دانشگاهى ' به عنوان محيط و صلاحيت حسابدارى دانشجو به عنوان خروجى استفاده كردند. نتايج يزوهش بيانكر اين بود كه شاخصهاى وران ورودى به به غير از

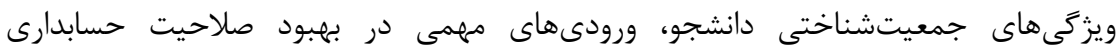

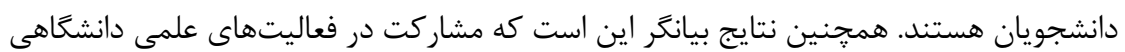
در رابطه بين ورودى ها و صلاحيت حسابدارى دانشجو نقش ميانجى را ايفا مى كند.

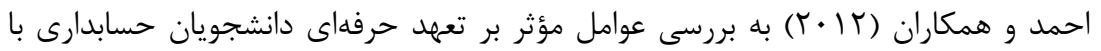

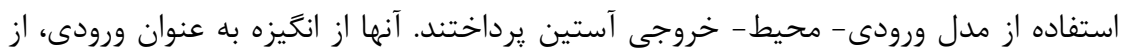

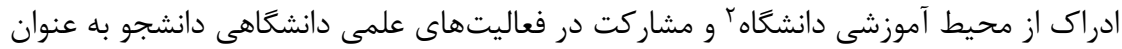

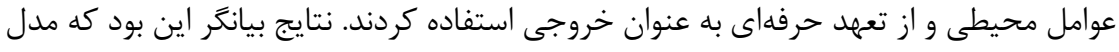

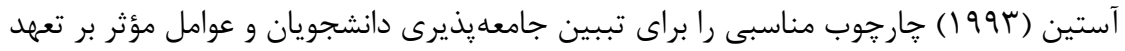
حرفهاى در دانشجويان فراهم مى آورد.

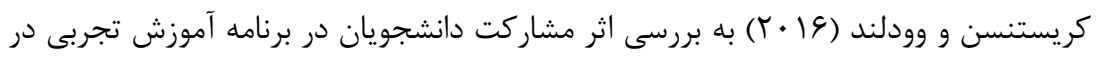

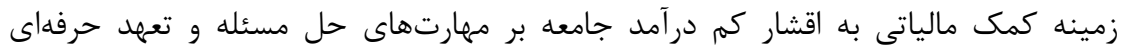

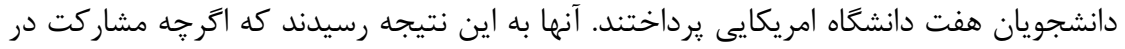

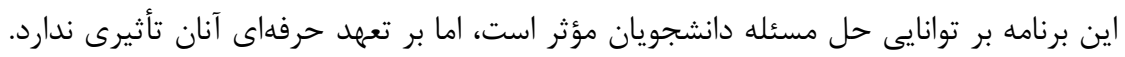

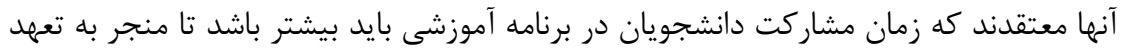
حرفهاى شود.

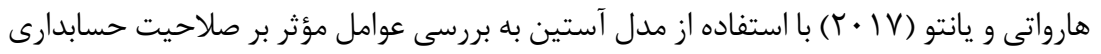

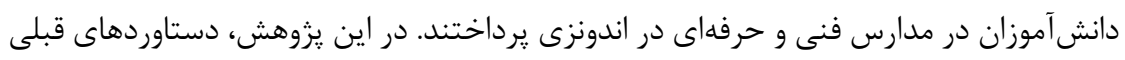

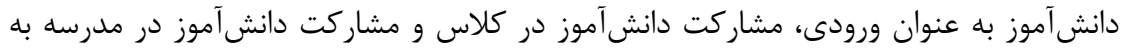

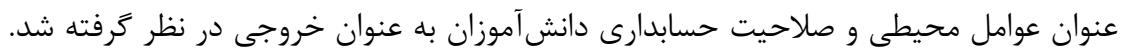

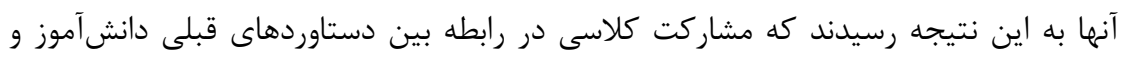

1. Involvement

2- Perceived environment 
صلاحيت حسابدارى نقش ميانجى ايفا مى كند.

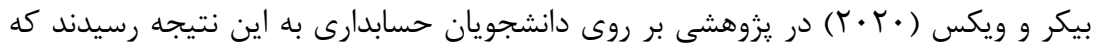

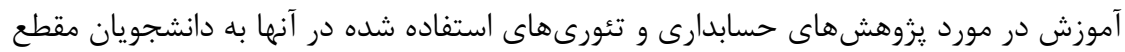

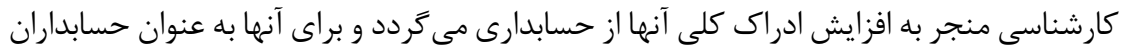

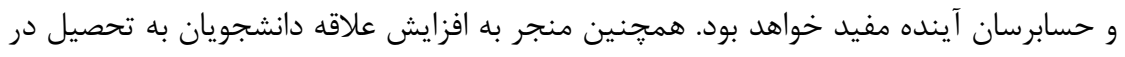

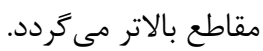

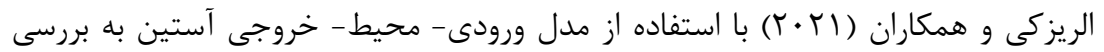

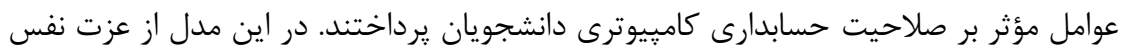

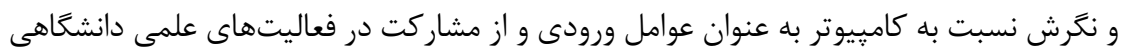

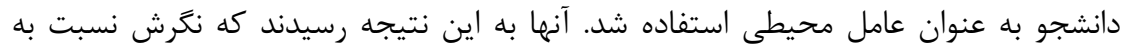

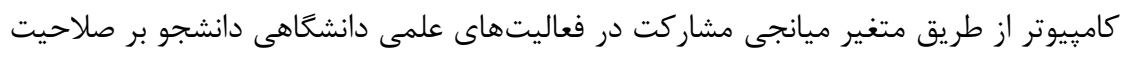
حسابدارى كاميبيوترى مؤثر است.

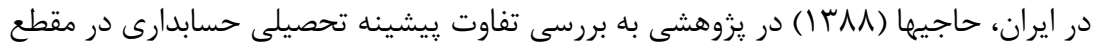

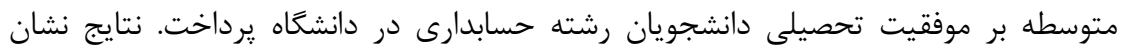

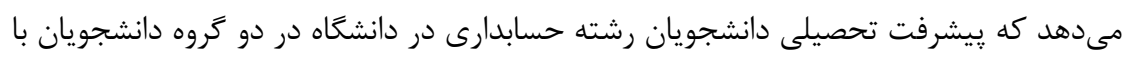

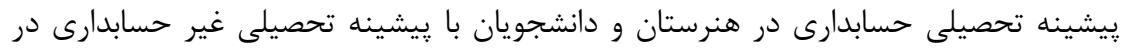

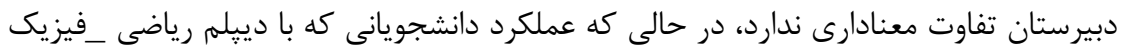

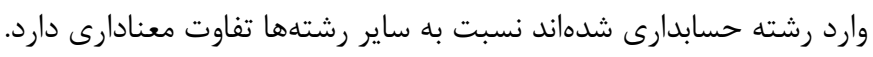

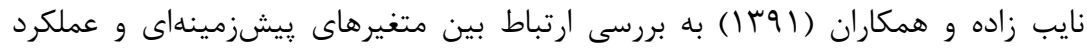

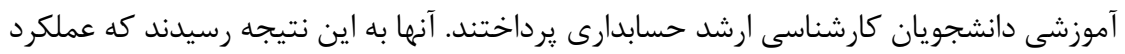

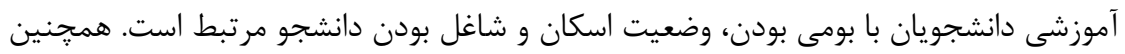

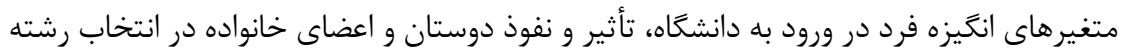

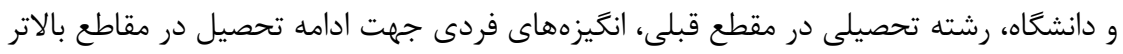

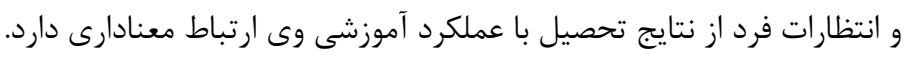

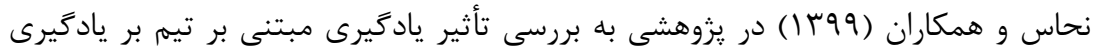

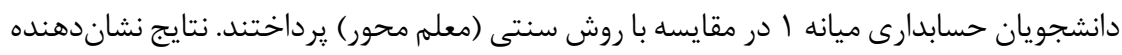

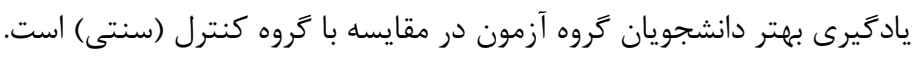

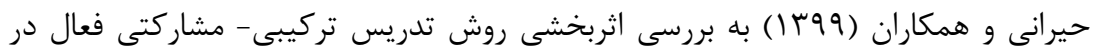

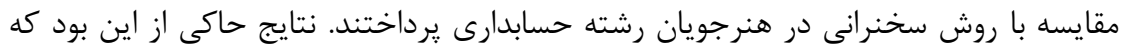

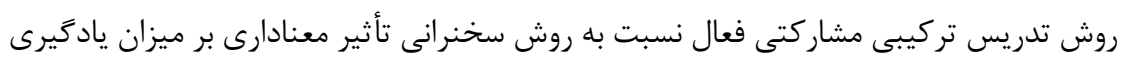




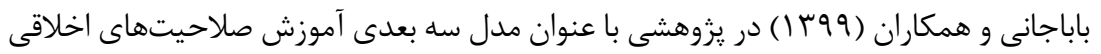

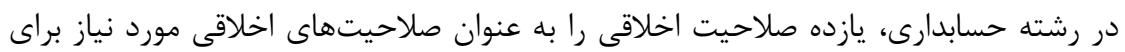

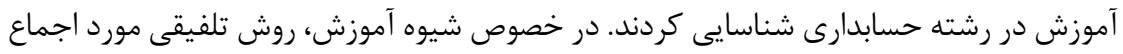

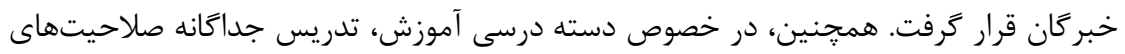

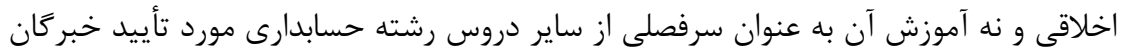

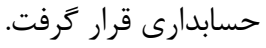

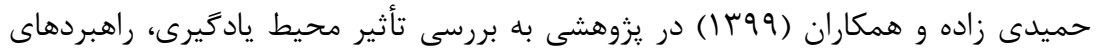

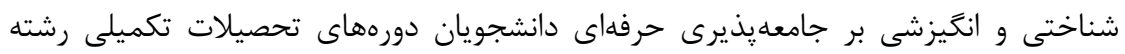

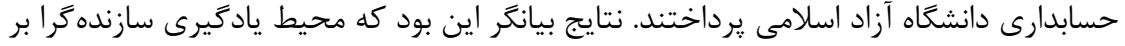

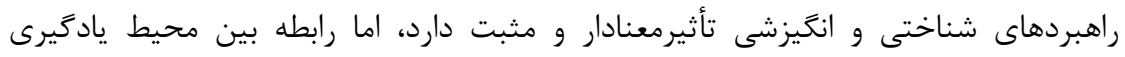

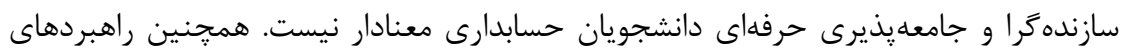

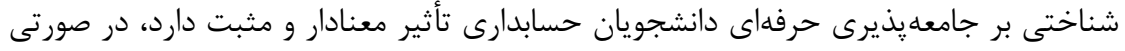

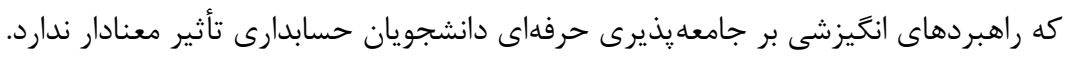

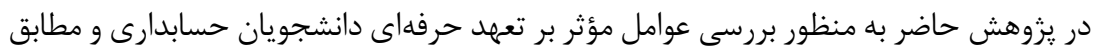

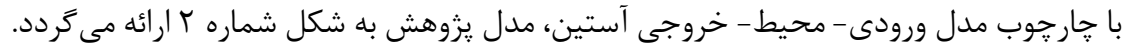

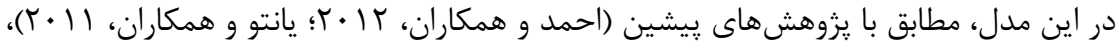

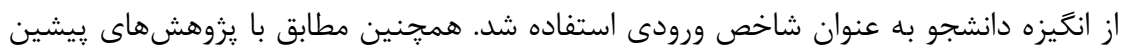

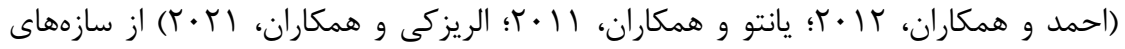

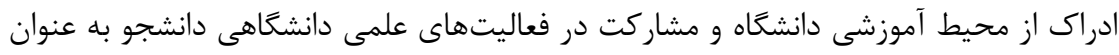

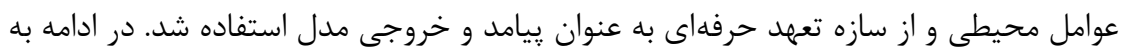

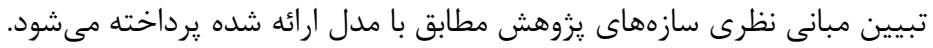

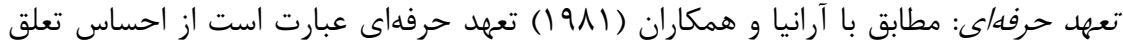

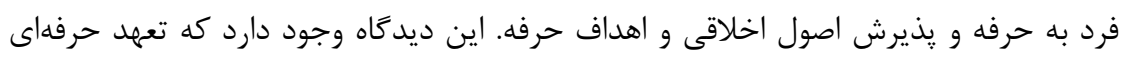

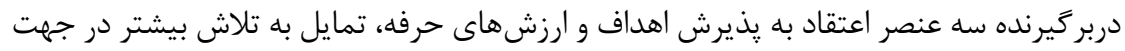

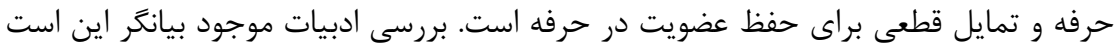

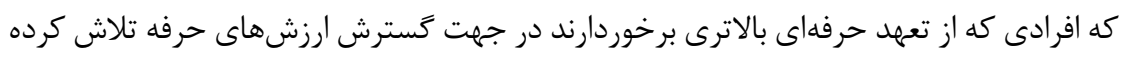

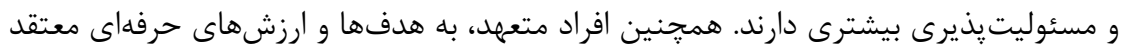

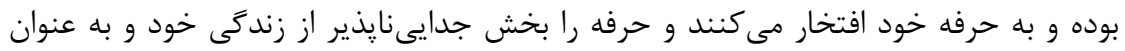


قسمتى از هويت خود مى دانند (زمانى و مهدوى، 99 و ا).

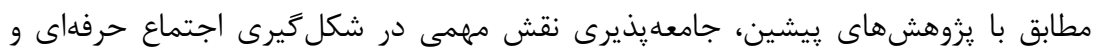

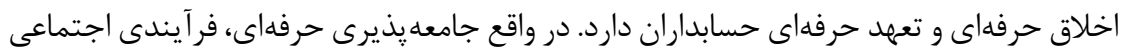

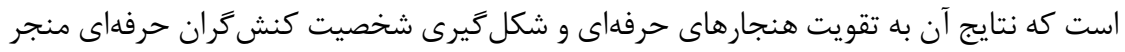

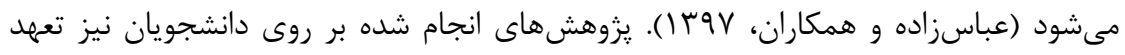

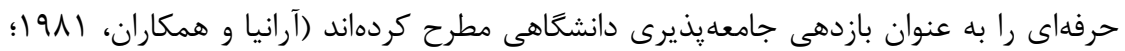

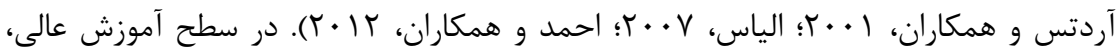

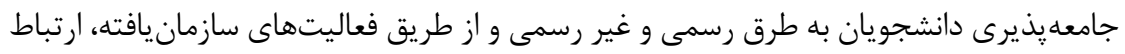

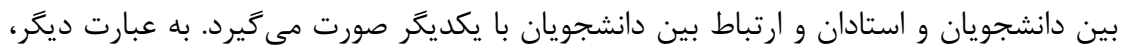
هم عوامل ساختارى (برنامه درسى رسمى) و هم نيروهاى بين فردى كه ناشى از تعاملهاى

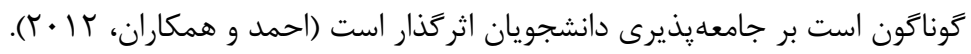

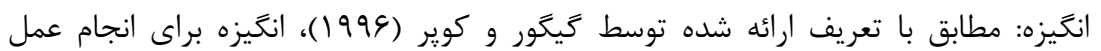

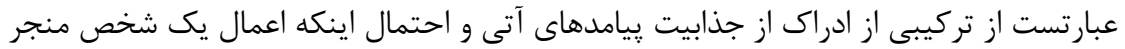

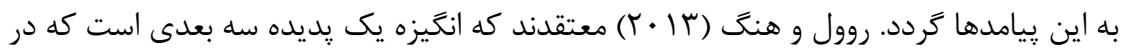

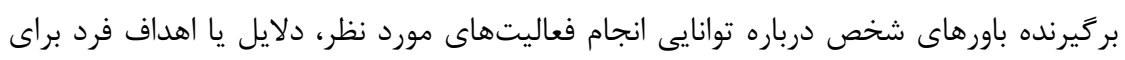

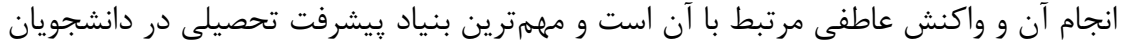

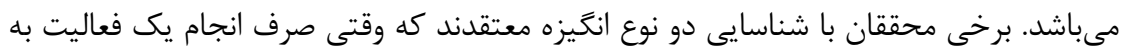

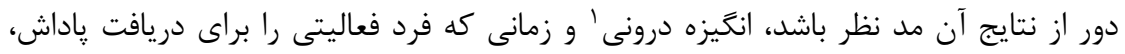

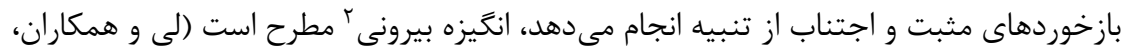

$$
(r \cdot 1
$$

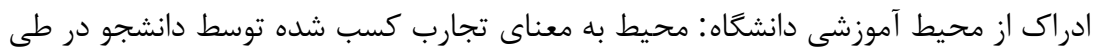

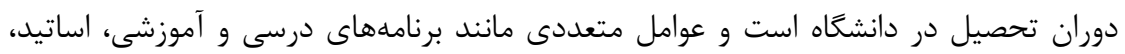

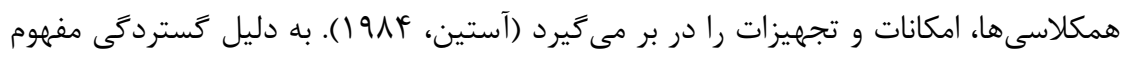

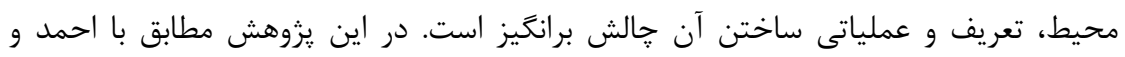

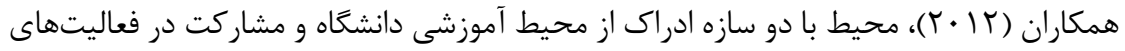

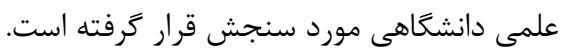

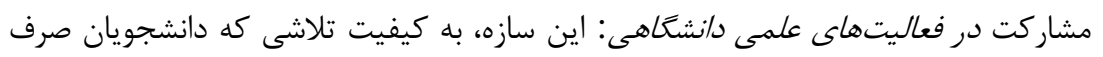

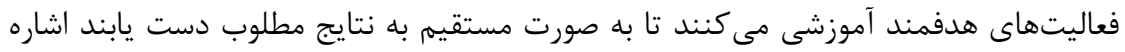

1. Intrinsic motivation

2- Extrinsic motivation 


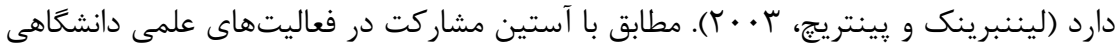

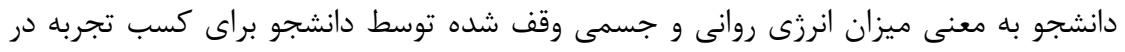

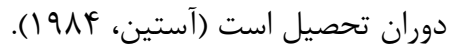

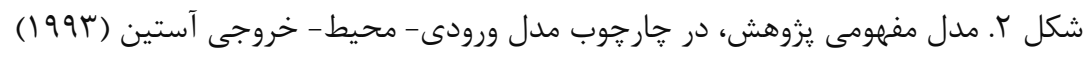

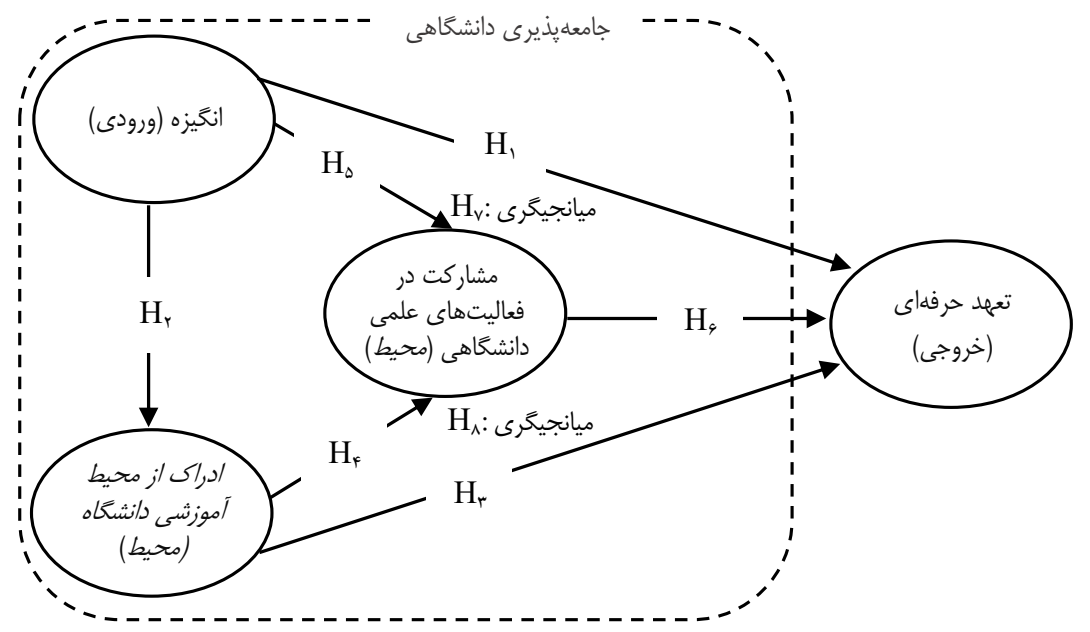

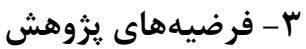

انغيزه در تمام فعاليتهاى زندكى فرد از جمله تحصيل، آموزش و يزوهش نقش مهرمى دارئ دارد و

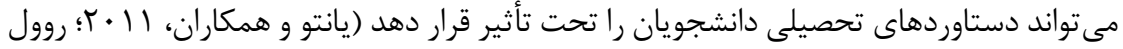

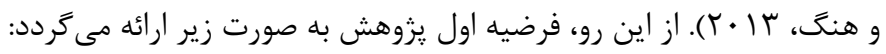

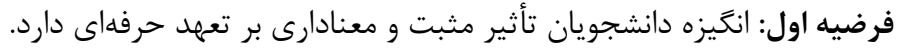

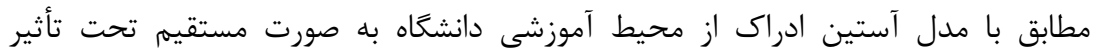

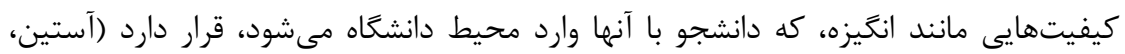

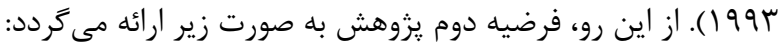

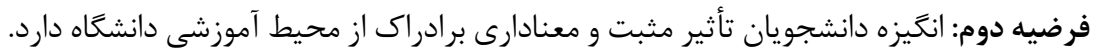

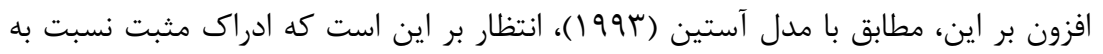

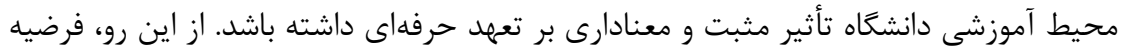

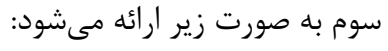
فرضيه سوم: ادراك مثبت نسبت به محيط آموزشى دانشكاه تأثير مثبت و معنادارى بر تعهد 


$$
\text { حرفهاى دانشجويان دارد. }
$$

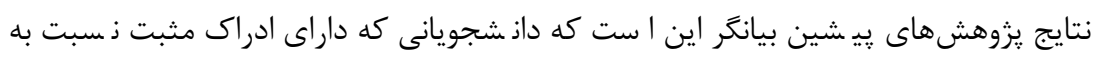

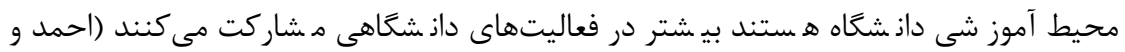

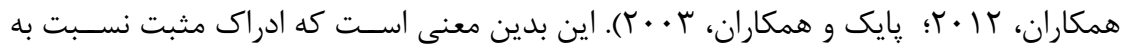

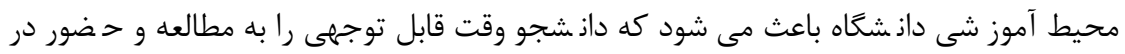

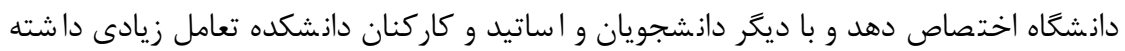

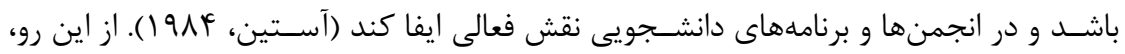

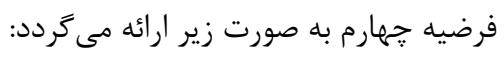

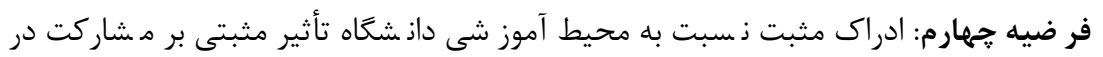

$$
\text { فعاليتهاى علمى دانشخاهى دانشجويان دارد. }
$$

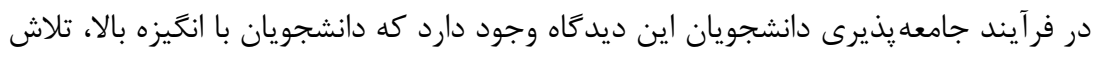

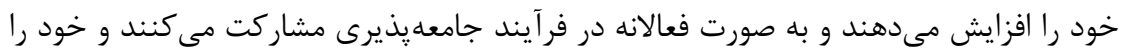

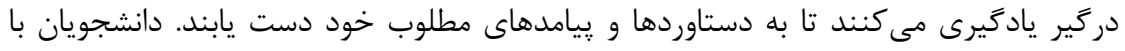

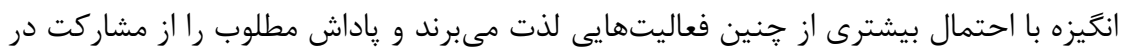

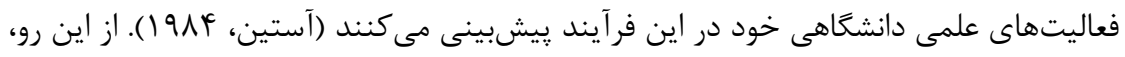

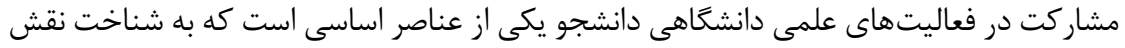

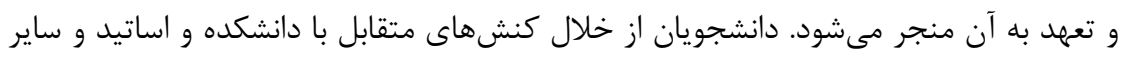

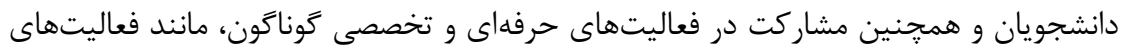

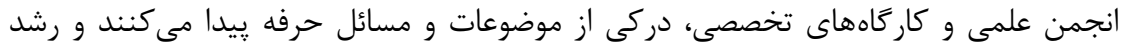

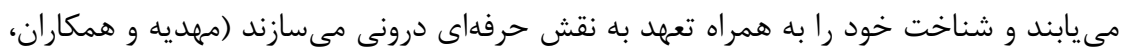

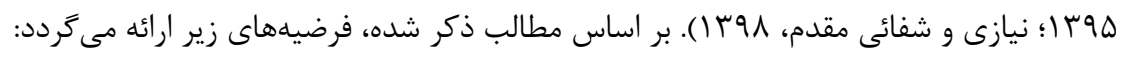

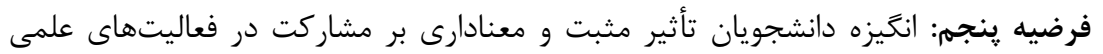

دانشخاهى آنها دارد. فرضيه ششم: مشاركت در فعاليتهاى علمى دانشخاهى دانشجويان تأثير مثبت و معنادارى بر تعهد حرفهاى آنان دارد.

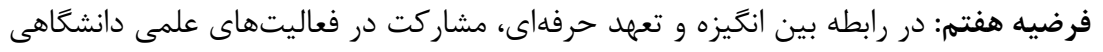
دانشجويان نقش ميانجى را ايفا مى كند. فرضيه هشته: در رابطه بين ادراك از محيط آموزشى دانشكاه و تعهد حرفهاى، مشاركت در 
فعاليتهاى علمى دانشخاهى دانشجويان نقش ميانجى را ايفا مى كند.

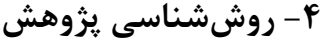

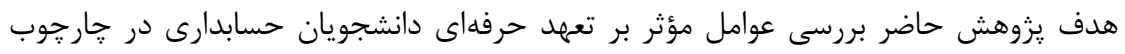

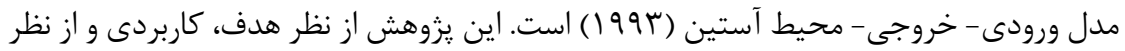

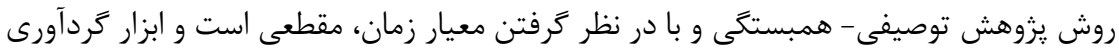

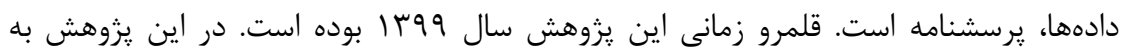

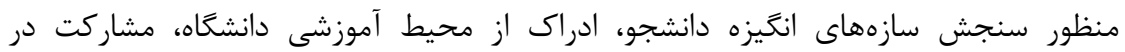

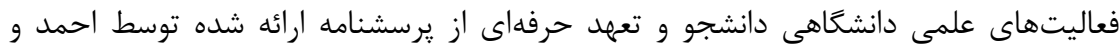

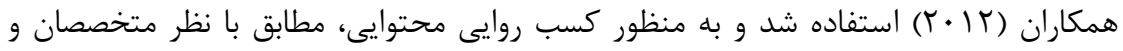

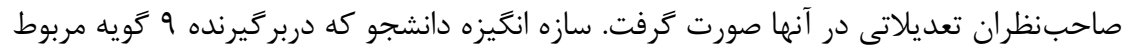

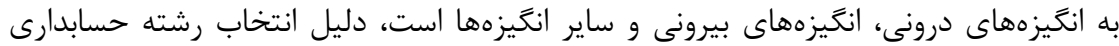

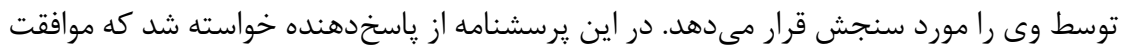

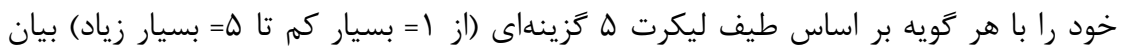
نمايد.

سازه ادراك از محيط آموزشى دانشكاه، ادراك دانشجويان از محيط فيزيكى دانشگاه،

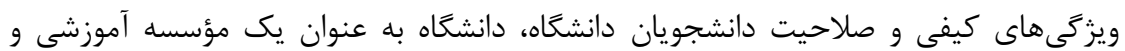

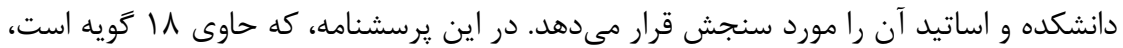

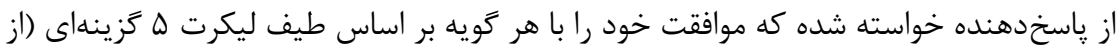
1= بسيار كم تا ه= بسيار زياد) بيان نمايد.

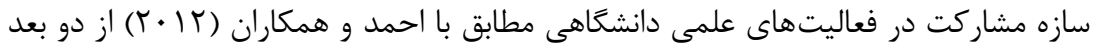

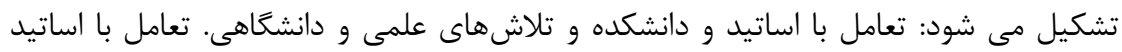

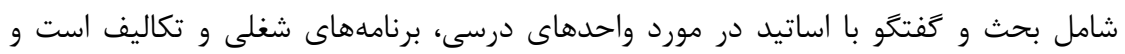

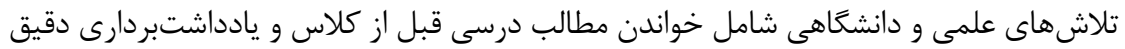

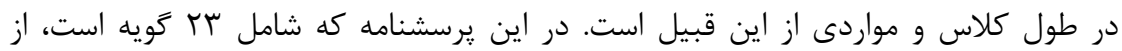

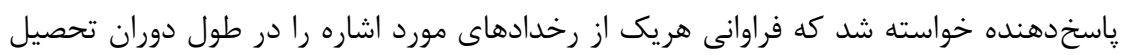
خود در دانشكاه بر اساس طيف ليكرت ه زَينهاى (از ا= هركز تا ه= هميشه) بيان نمايد.

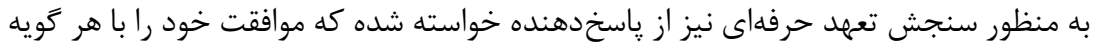

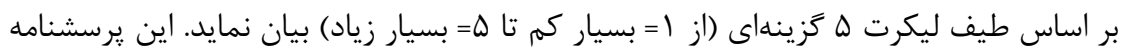




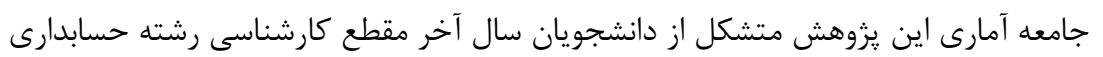

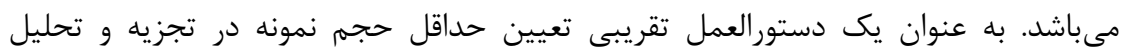

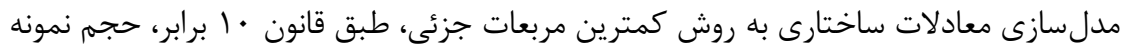

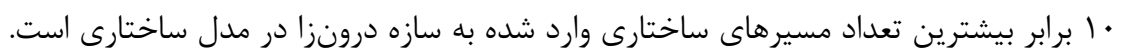

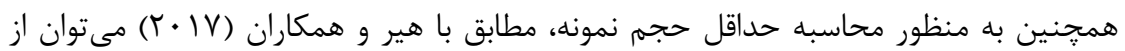

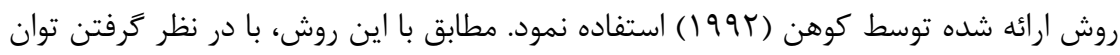

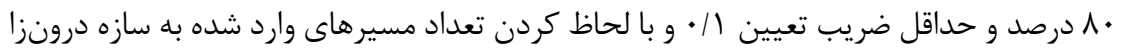

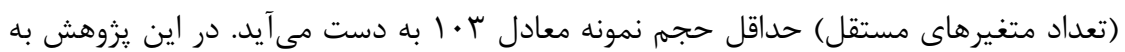

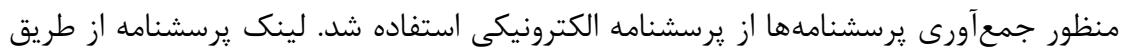

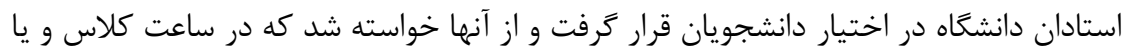

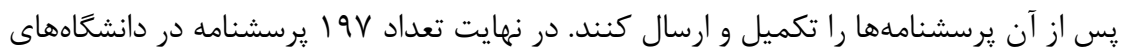

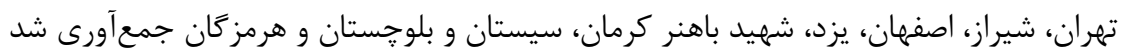

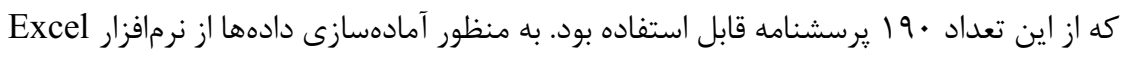

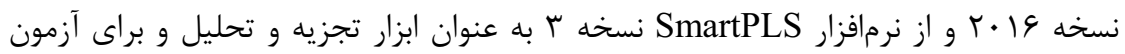

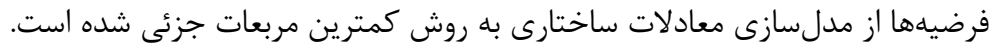

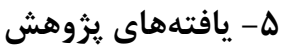
جدول شماره ا، آمارههاى توصيفى متغيرهاى مورد مطالعه شامل ميانكَين و انحراف استاندارد، جولخى و كشيدگى را نشان مى نهد. جدول 1: آمار توصيفى سازههاى يزوهش

\begin{tabular}{|c|c|c|c|c|}
\hline 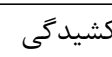 & جولنى & نحراف معيار & ميانگين & متغير \\
\hline $1 / 4 \cdot 1$ & $-. / 9 V /$ & - /9人ץ & r/qFT & تعهد حرفهاى \\
\hline.- .1191 & - . Atrt & M/lFF & $r / 9 \Delta \Lambda$ & 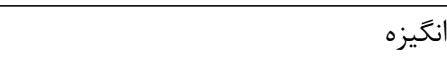 \\
\hline$-0 / \pi 9$. &.$-|A T|$ & $1 / \cdot r$. & $\Gamma / \Gamma \cdot \Delta$ & ادراك از محيط آموزشى دانشگاه \\
\hline .1 .94 & $-\cdot /$ FH & $1 / 1 M \Lambda$ & Tr/T & مشاركت در فعاليتهاى علمى دانشخاهى \\
\hline
\end{tabular}

همانطور كه در جدول املاحظه مى شــود متغيرهاى تعهد حرفهاى و مشــاركت در فعاليتهاى

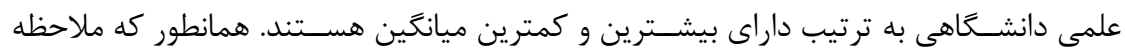

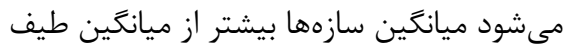


(r) مىباشد و مقادير جولنى و كشيدگى در كران ا- و | + نشان از توزيع متقارن دادهها دارد.

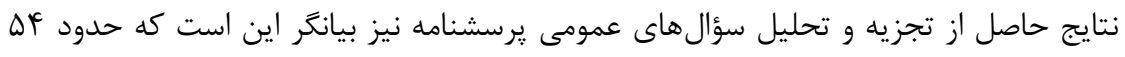

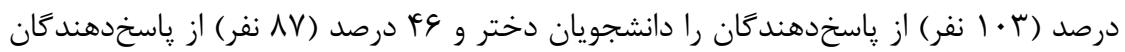

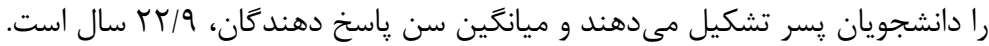
ارزيابى مدلهاى اندازهَيرى

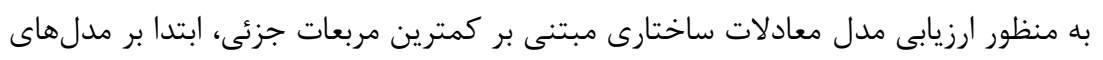

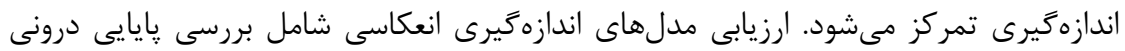

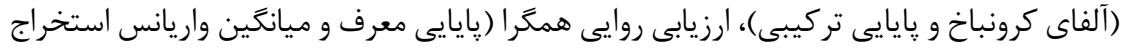

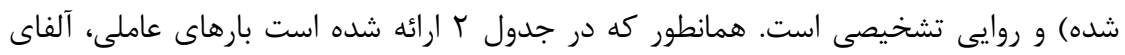

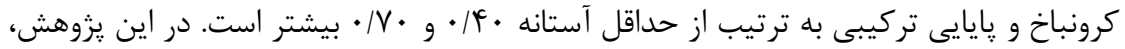

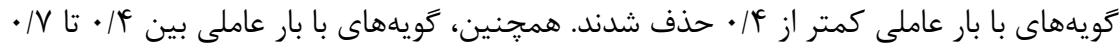

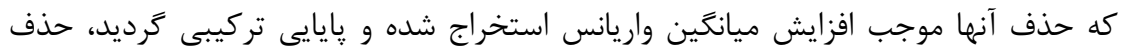

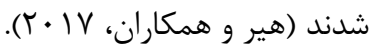

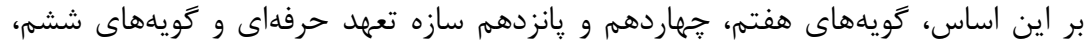

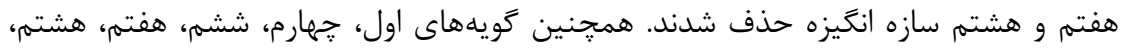

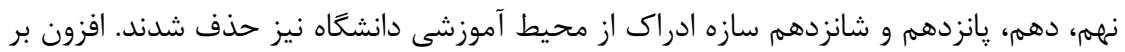

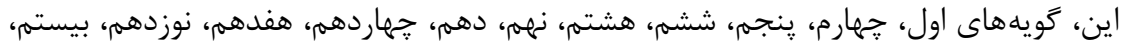

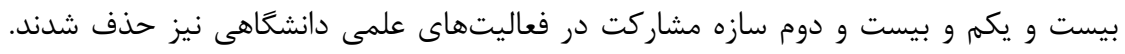

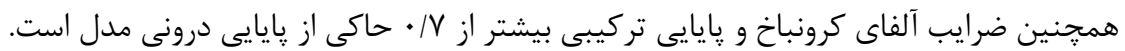

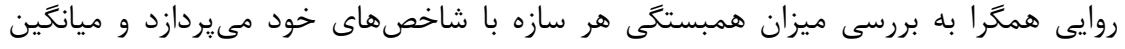

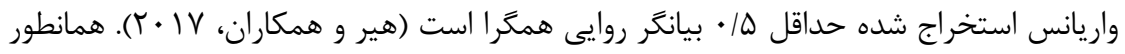

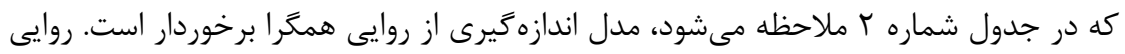

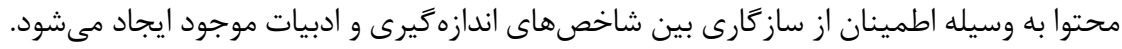

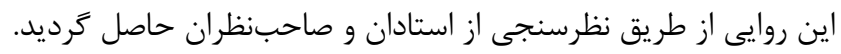

\begin{tabular}{|c|c|c|c|c|c|c|}
\hline \multicolumn{7}{|c|}{ جدول r: روايى همخرا و پايايى ابزار اندازمخيرى } \\
\hline آلفاى & بايايى & معنادار & t & بارهاى & ميانكين واريانس & \\
\hline كرونباخ & تركيبى & $\mathrm{s}$ & ا & عاملى & استخراج شده & معير \\
\hline.$/ 9 \mathrm{~V}$ &.$/ 9 \% \Delta$ & & & & $\cdot / \Delta V r$ & تعهد حرفهاى \\
\hline & & $\cdot \ldots$ & IT/GKT & $\cdot / \mathrm{V} M \mathrm{~A}$ & & كويه 1 كويه \\
\hline & &.$/ \ldots$ & $1 . / K F 4$ & $\cdot \mid 9 \vee 9$ & & r كويه \\
\hline
\end{tabular}


دوفصلنامه حسابدارى ارزشى و رفتارى، سال ششم، شماره يازدهم، بهار و تابستان +. عا

\begin{tabular}{|c|c|c|c|c|c|c|}
\hline & & $\cdot 1 \cdots$ & $r \cdot / \Lambda 99$ & - MAT & & كويه r \\
\hline & & $\cdot 1 \cdots$ & $|r / r| \mid$ & . MAt & & Fويه F \\
\hline & & $\cdot 1 \cdot$ & $1 \Lambda / V \cdot \Lambda$ & $\cdot / N 1 D$ & & كويه ه \\
\hline & & $\cdot 1 \cdot$ & tV/frq & $\cdot$. VGF & & كويه 4 \\
\hline & & $.1 \cdots$ & ra/Art & $\cdot \mid \Lambda F \Delta$ & & كويه 1 \\
\hline & & $\cdot 1 \cdots$ & TM/TFt & - /V9V & & كويه 9 \\
\hline & & $\cdot 1 \cdots$ & rN/Fq1 & $\cdot \mid \Lambda V F$ & & كويه · \\
\hline & & $\cdot 1 \cdots$ & TF/qr. & $\cdot / \Lambda T \Delta$ & & كويه 11 \\
\hline & & $.1 \cdots$ & TI/THD & $\cdot / V \wedge \Delta$ & & كويه r| \\
\hline & & $\cdot 1 \cdots$ & $9 / 1 / 0$ & $\cdot 109 \Delta$ & & كويه سا \\
\hline & & $\cdot 1 \cdots$ & $\mid F / F r \Lambda$ & $\cdot N \cdot r$ & & كويه 19 \\
\hline \multirow[t]{7}{*}{ - 1 A 99} & $\cdot / \wedge \vee \wedge$ & & & & $\cdot \mid \Delta \Delta \Lambda$ & |نخيزه \\
\hline & & $\cdot 1 \cdots$ & $r T / / \Delta \Delta$ & $\cdot / \vee \wedge \Lambda$ & & كويه 1 \\
\hline & & $\cdot 1 \cdots$ & $\Delta V / T F I$ & .191. & & كويه r \\
\hline & & $\cdot 1 \cdots$ & $N \cdot 1 \mathrm{~L}$ & .1911 & & كويه r \\
\hline & & $\cdot 1 \cdots$ & F/ANT & $\cdot / 4 G 4$ & & كويه F \\
\hline & & $\cdot 1 \cdots$ & D)/V^q & $\cdot 19 \cdot 9$ & & كويه ه \\
\hline & & $\cdot 1 \cdots$ & $1 D / 9 \Delta F$ & .1994 & & كويه 9 \\
\hline \multirow[t]{10}{*}{$\cdot / 9 \cdot r$} & .1919 & & & & $\cdot 1099$ & ادراك از محيط آموزشى دانشحاه \\
\hline & & $\cdot 1 \cdots$ & $r F / I r \Lambda$ & . /199 & & كويه r \\
\hline & & $\cdot 1 \cdots$ & $r F / r q$. & .1970 & & كَويه r \\
\hline & & $\cdot 1 \cdots$ & $11 / \cdot \Delta 9$ &.$|9| 0$ & & كويه ه \\
\hline & & $\cdot 1 \cdots$ & FN/TG. & .1941 & & كويه 11 \\
\hline & & $\cdot 1 \cdots$ & $f / 4<\mid$ & $\cdot|D| T$ & & كويه $\mid$ \\
\hline & & $\cdot 1 \cdot$ & $\Delta / \tau \cdot V$ & $\cdot \mid \Delta V T$ & & كويه سا \\
\hline & & $\cdot 1 \cdots$ & $r \cdot / 9 r \wedge$ & .1911 & & كويه \\
\hline & & $\cdot 1 \cdot$ & $9 / .1 V$ & .1090 & & كويه V V \\
\hline & & $\cdot 1 \cdots$ & $11 / 1 \wedge \Delta$ & .1991 & & كويه 11 \\
\hline \multirow[t]{5}{*}{$\cdot 11999$} & .1911 & & & & . IDTT & 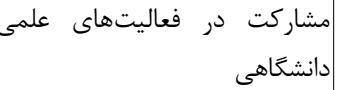 \\
\hline & & $\cdot 1 \cdot$ & IT/ITT & .1999 & & كويه r \\
\hline & & $\cdot 1 \cdots$ & $|r / \cdot r|$ & .1991 & & كويه r \\
\hline & & $\cdot 1 \cdot$ & I $1 / \Delta \mathrm{H}^{\circ}$ & - INFG & & Vويه V \\
\hline & & $\cdot 1 \cdots$ & V/TVT & $\cdot 109 \Delta$ & & كويه 11 \\
\hline
\end{tabular}




\begin{tabular}{|c|c|c|c|c|c|}
\hline & & $\cdot / \cdots$ & ID/ITT & - IATV & كويه r| \\
\hline & & $\cdot / \cdots$ & 1.1948 & - /VDr & كويه سا \\
\hline & & $\cdot 1 \cdots$ & $V / 19 r$ & .109. & كويه ها \\
\hline & & $\cdot 1 \cdots$ & $I r / \Lambda \Lambda F$ & $\cdot 11 \cdot 9$ & كويه 19 \\
\hline & & $\cdot 1 \cdots$ & N/TFF & $\cdot|\Delta \wedge\rangle$ & كويه 11| \\
\hline & & $\cdot / \cdots$ & 1 1//rqV & - $\mid \wedge \vee \Delta$ & كويه سץ \\
\hline
\end{tabular}

در اين يروهش جهت بررسى روايى تشخيصى از معيار فورنل- لاركر و نسبت خصيصه متفاوت، خصيصه يكسان استفاده شده است. معيار فورنل- لاركر از طريق مقايسه جذر ميانگين واريانس استخراج شده با همبستخى بين سازهها (جدول شماره ب) سنجيده شده و براى هركدام از سازههاى انعكاسى جذر ميانگين واريانس استخراج شده بايد بيشتر از همبستكى آن سازه با ساير

$$
\text { سازمهاى مدل باشد. }
$$

جدول "ا: ماتريس فورنل- لاركر جهت بررسى روايى تشخيصى

\begin{tabular}{|c|c|c|c|c|}
\hline فعاليتهاى علمت داركى & آدراك از مححيط & 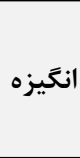 & حرفهاى & متغير \\
\hline & & & $\cdot / V \Delta V$ & تعهد حرفهاى \\
\hline & & $\cdot / V F V$ & $\cdot 10 \cdot \cdot$ & 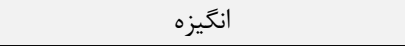 \\
\hline & $\cdot / V \Delta F$ & $\cdot \pi \cdot V$ &.$/ 219$ & ادراى از محيط آموزشى دانشكاه \\
\hline$\cdot / \mathrm{VH} \cdot$ & $\cdot / T+D$ & $\cdot \pi \cdot r$ & 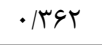 & مشاركت در فعاليتهاى علمى دانشخاهى \\
\hline
\end{tabular}

همجنين، نسبت خصيصه متفاوت، خصيصه يكسان همبستگَى بين خصيصه هاى متفاوت به خصيصههاى يكسان را نشان مى دهد. بنابراين در اين رويكرد، هرجه همبستخى خصيصههاى

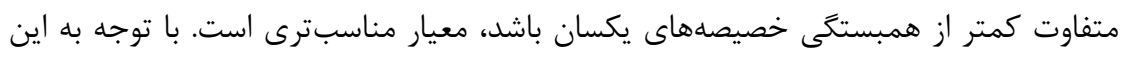
نسبت، مطابق با جدول شماره F زمانى روايى تشخيصى بين دو سازه انعكاسى وجود دارد كه اين مقدار حداكثر 9/ • باشد (هير و همكاران، IV • (Y).

\begin{tabular}{|c|c|c|c|c|}
\hline فعاليتهاى علمى داركت در & آموزشى دانش از محيطاه & انخيزه & حرفهاى تعهد & متغير \\
\hline & & & & تعهد حرفهاى \\
\hline & & & $\cdot / \Delta F \Lambda$ & |انخيزه \\
\hline & & ( ) & $\cdot / r \Delta \Delta$ & | ادراك از محيط آموزشى دانشكاه \\
\hline & $\cdot / r \Delta \cdot$ & • & $\cdot /$ rVA & مشاركت در فعاليتهاى علمى دانشخاهى \\
\hline
\end{tabular}




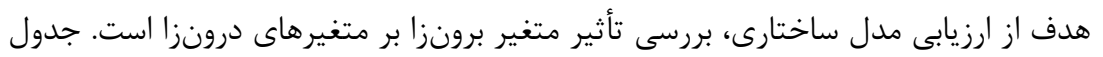

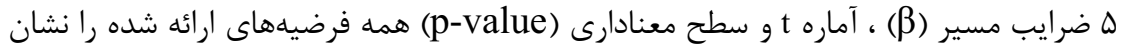

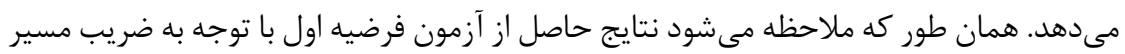

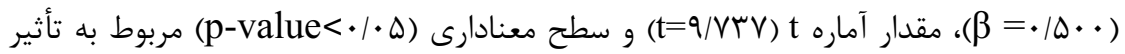

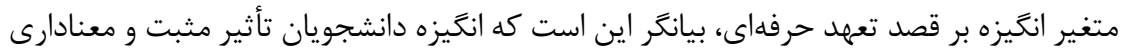

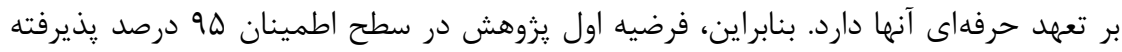

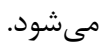

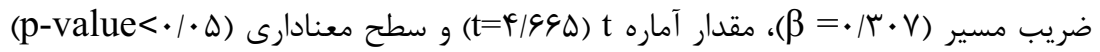

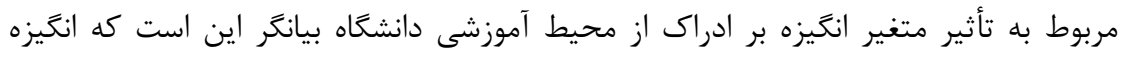

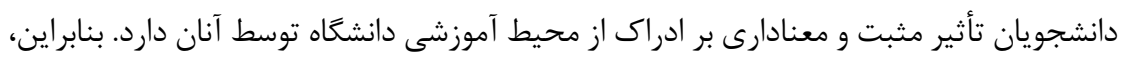

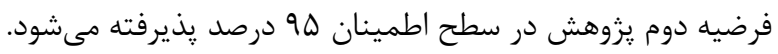

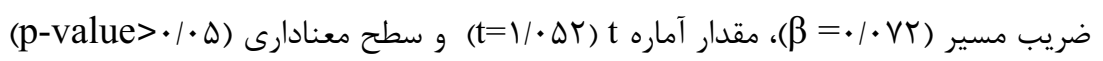

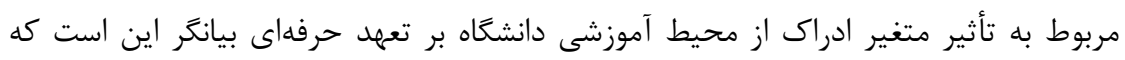

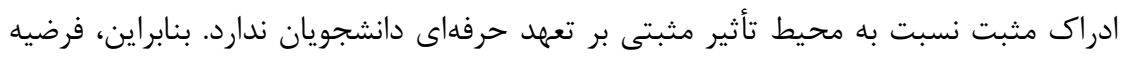

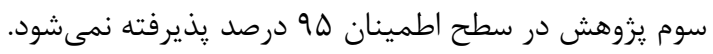

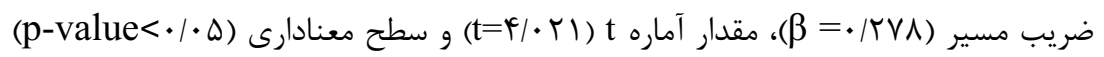

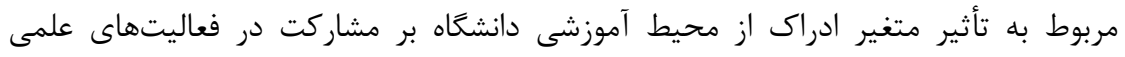

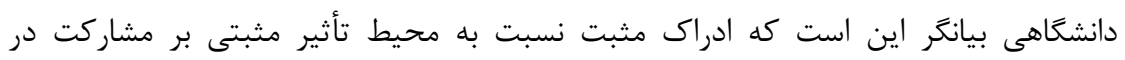

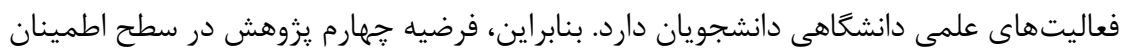

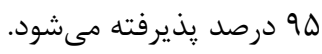

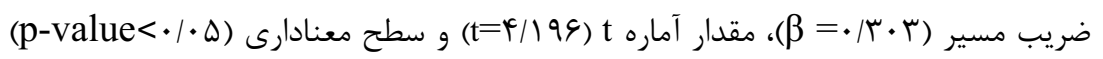

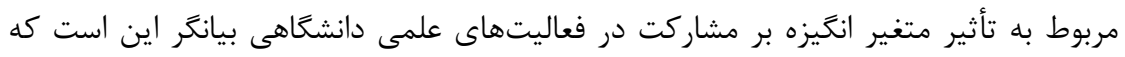

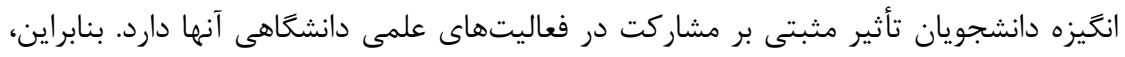

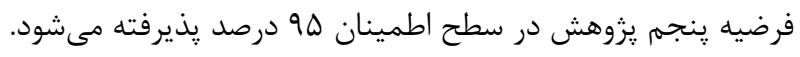

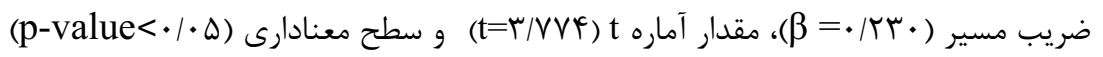

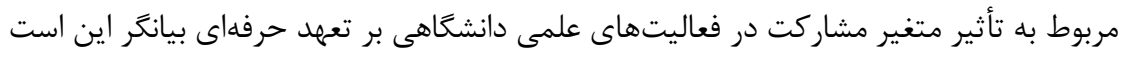

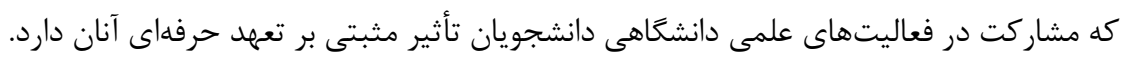

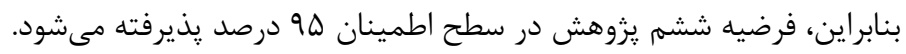


براى آزمون فرضيه هفتم، كه مربوط به اثر غيرمستقيم انخيزه بر تعهد حرفهاى است، از روش

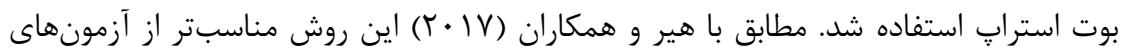

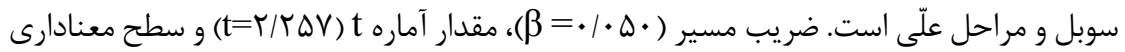

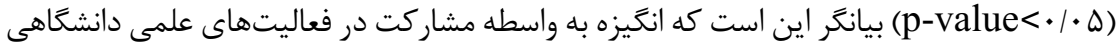

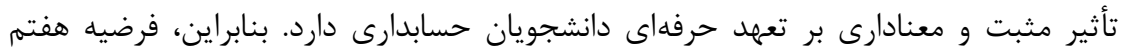

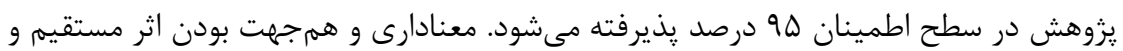

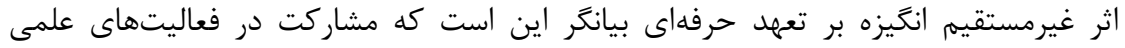

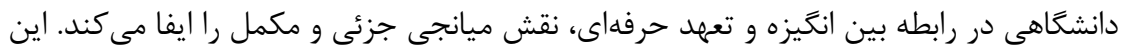

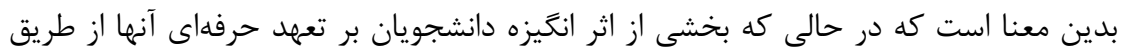

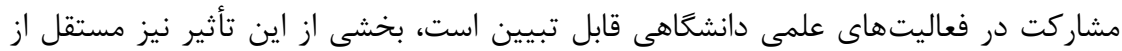

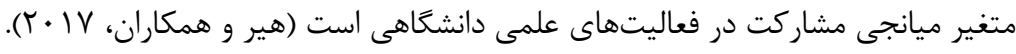
جدول ه: نتايج حاصل از آزمون فرضيهها

\begin{tabular}{|c|c|c|c|c|c|}
\hline يذ پذيرش/عدم & 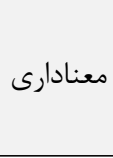 & 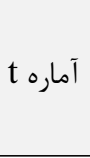 & 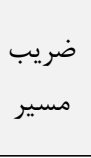 & مسير & |فرضيه \\
\hline 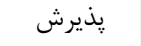 & $\cdot 1 \cdot \cdots$ & १/VrV & $\cdot / \Delta \cdots$ & |انخيزه ـ تعهد حرفهاى & 1 \\
\hline يذيرش & $\cdot 1 \cdot \cdots$ & $\varphi / 99 \Delta$ & $\cdot / \mu \cdot v$ & |انخَيزه ـ ـ ادراك از محيط آموزشى دانشكاه & $r$ \\
\hline عدم يذيرش & $\cdot / r q 4$ & $1 / \cdot \Delta r$ & $\cdot / \cdot \mathrm{VT}$ & |دراك از محيط آموزشى دانشكاه ـ تعهد حرفهاى & $r$ \\
\hline يذيرش & $\cdot / \cdots$ & $F / \cdot r_{1}$ & $\cdot /$ rVA & 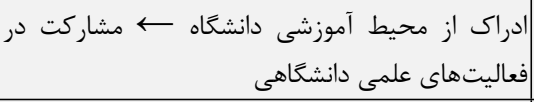 & f \\
\hline يذيرش & $\cdot 1 \cdot$ & $4 / 199$ & $\cdot / \mu \cdot r$ & انخيزه ـ ـ مشاركت در فعاليتهاى علمى دانشخاهى & $\Delta$ \\
\hline 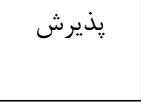 & $\cdot 1 \cdot$ & r/VVF & . & مشرفاركت در فعاليتهاى علمى دانشخاهى ـ ـ تعهد & \& \\
\hline يذيرش & $\cdot / \cdot r f$ & $r / T \Delta V$ & $\cdot / \cdot \Delta \cdot$ & | & v \\
\hline يذيرش & $\cdot 1 \cdot \cdot \Delta$ & r/ATI & .1 .94 & 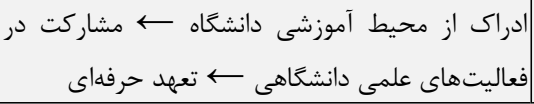 & $\wedge$ \\
\hline
\end{tabular}

براى آزمون فرضيه هشتم، كه مربوط به اثر غيرمستقيم ادراك از محيط آموزشى دانشكاه بر

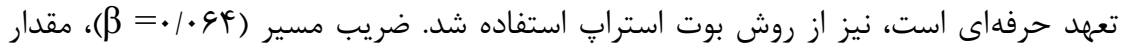

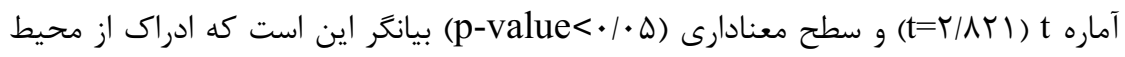


آموزشى دانشخاه به واسطه مشاركت در فعاليتهاى علمى دانشآهى تأثير مثبت و معنادارى بر

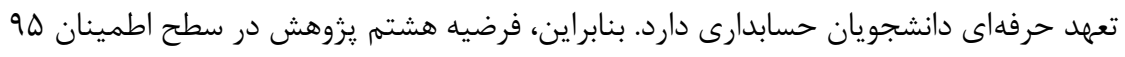

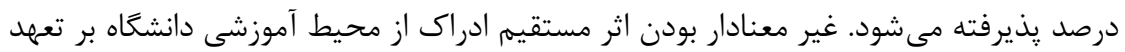

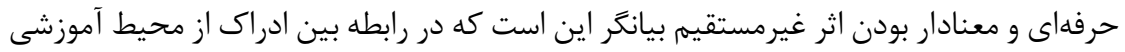

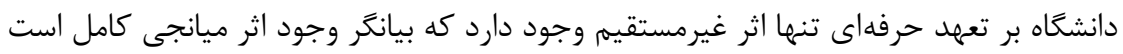

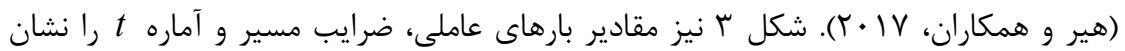
شكل سا: مقادير بارهاى عاملى، ضرايب مسير و آماره |

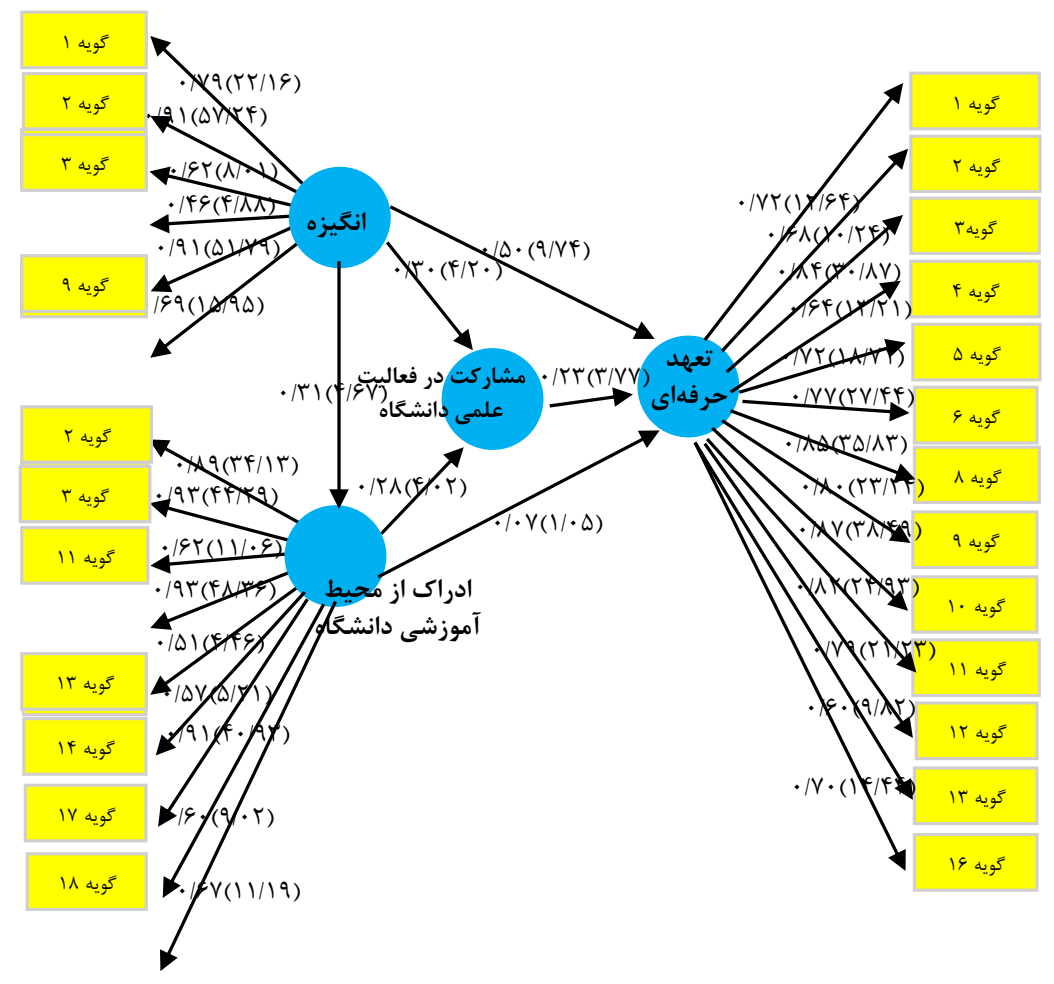




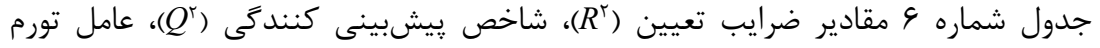

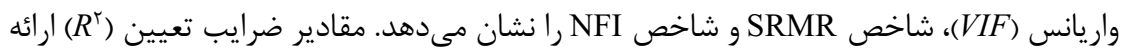

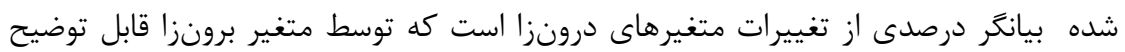

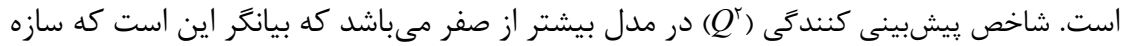

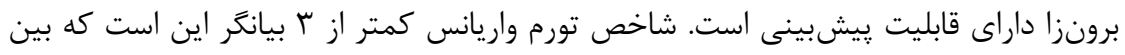

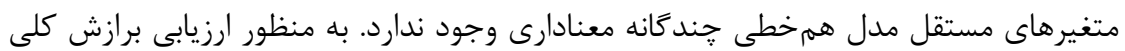

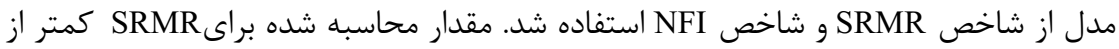

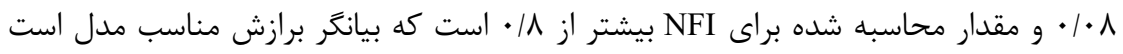

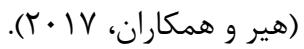

\begin{tabular}{|c|c|c|c|c|c|c|}
\hline \multicolumn{7}{|c|}{ جدول 9: نتايج حاصل از ارزيابى مدل ساختارى } \\
\hline$N F I$ & SRMR & شاخص & $\begin{array}{c}\text { بيشبينى كنندكى } \\
\left(Q^{r}\right)\end{array}$ & ضريب تعيين & ضين ضريب (R) & متغيرها \\
\hline - /AVG & $.1 .9 \mathrm{~V}$ & & $\cdot / 1 \Delta \Lambda$ & $\cdot / T \wedge \Lambda$ & $\cdot / 799$ & تعهد حرفهاى \\
\hline & & $1 / 19$. & & & & انكَيزه \\
\hline & & $1 / 199$ & $.1 \cdot 4 \mathrm{~V}$ & $\cdot 1 \cdot 19$ & .1 .94 & دانشكاه از محيط آموزشى \\
\hline & & $1 / 194$ & $\cdot / \cdot v 9$ & $\cdot / l \Delta r^{2}$ & - /IST & علمى دانشكاهى د فعاليتهاى \\
\hline
\end{tabular}

\section{9- ونتيجه كيرى و بحث}

هدف اين يزوهش بررسى عوامل مؤثر بر تعهد حرفهاى دانشجويان حسابدارى در نتيجه فرآيند

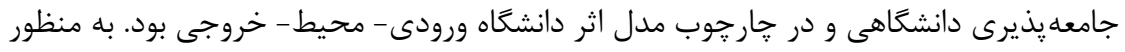
دستيابى به اين هدف، هشت فرضيه مطرح شد و با روش كمترين مربعات جزئى مورد سنجش آنس

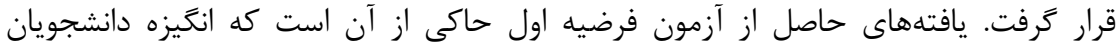

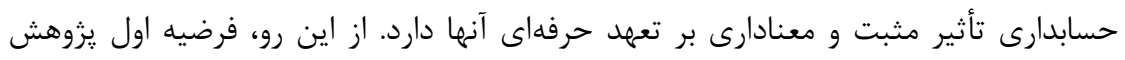

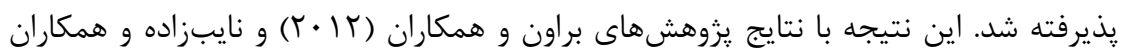

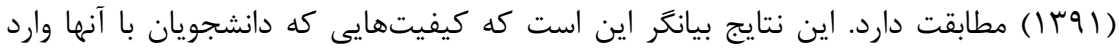

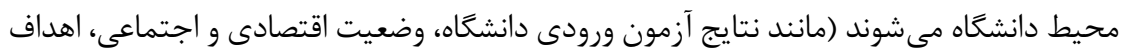
زندكى و متغيرهاى جمعيت شناختى) و دلايل انتخاب رشته توسط آنها بر تعهد حرفهاى آنهائ 
تأثير كذار است؛ به عبارت ديخر، جامعهيذيرى نسبت به حرفه حسابدارى و پيامد آن يعنى تعهد

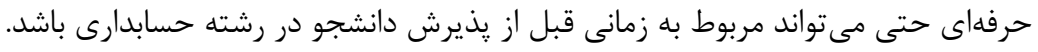

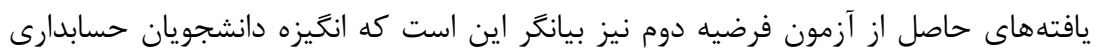

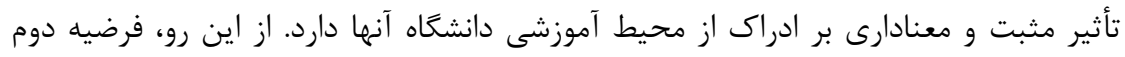

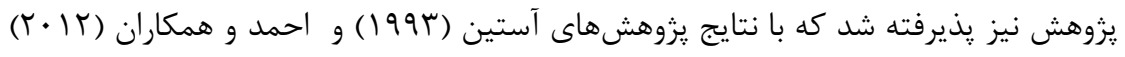

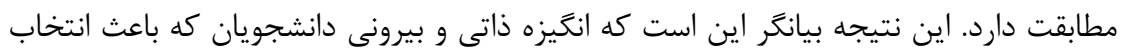

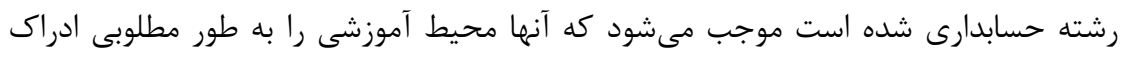
كنند. يافتههاى حاصل از آزمون فرضيه سوم بيانكر اين است كه ادراك از محيط آموزشى دانشكاه

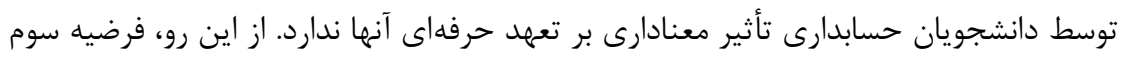

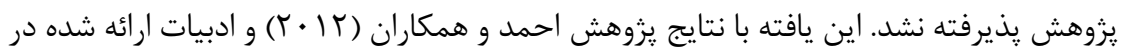

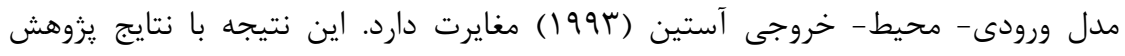

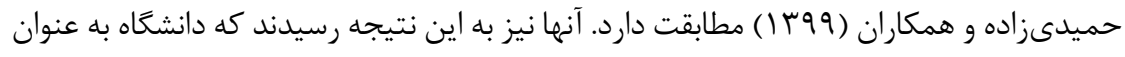

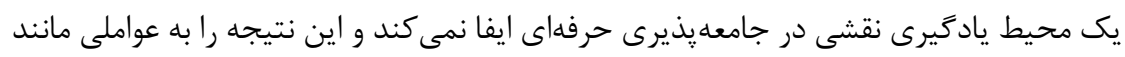

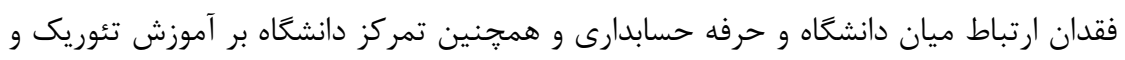

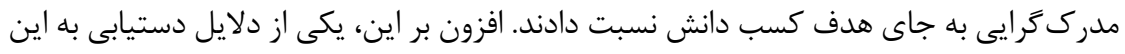

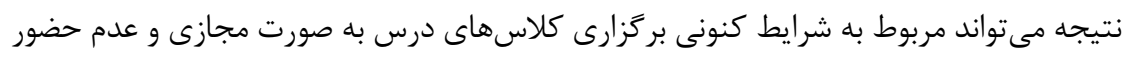
دانشجويان در محيط دانشعاه باشد.

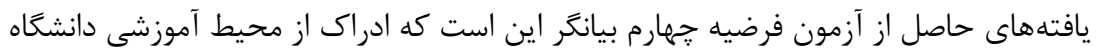

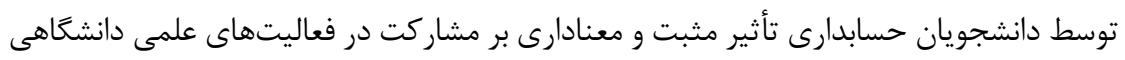

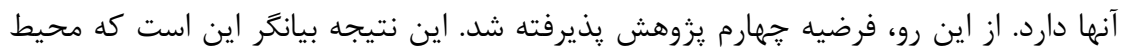

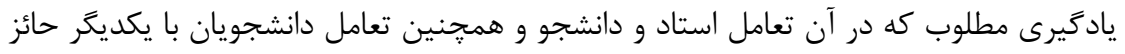

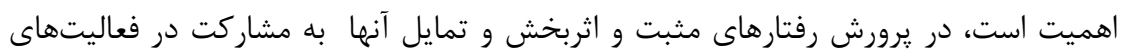

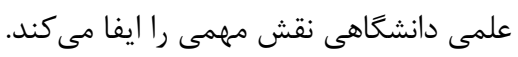

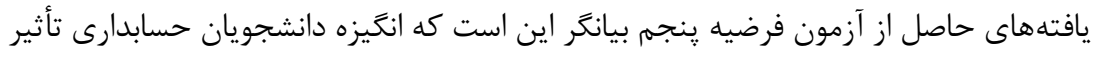

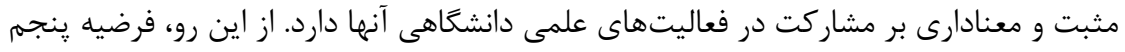

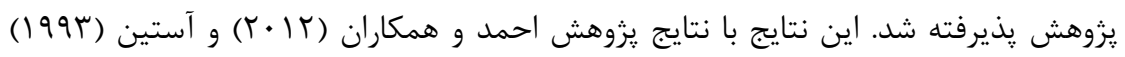

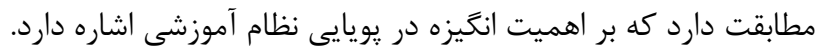

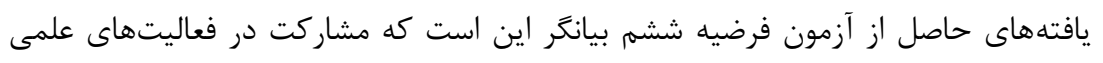

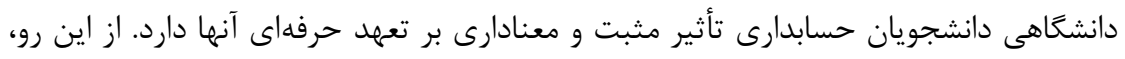




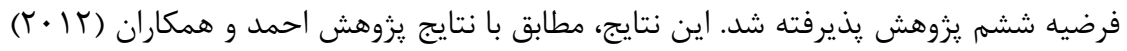

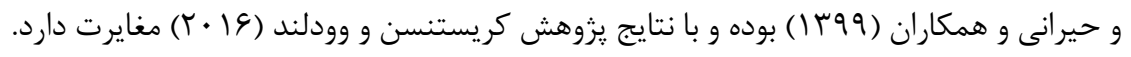

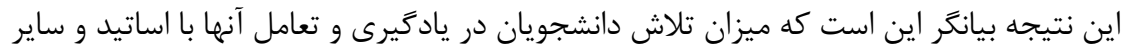

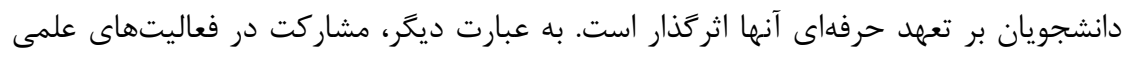

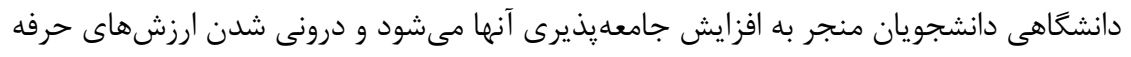

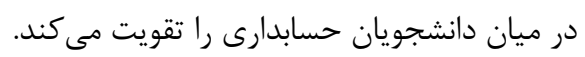

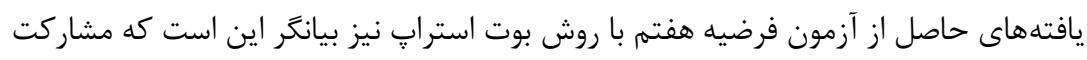

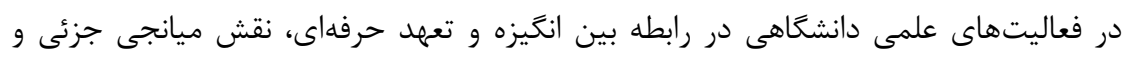

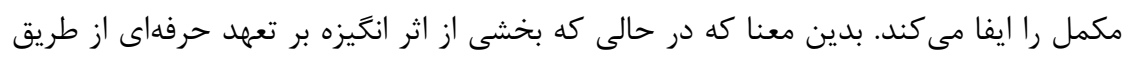

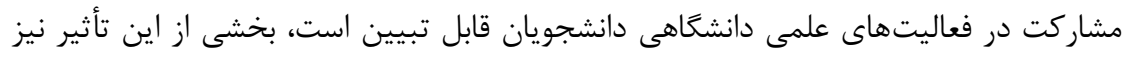

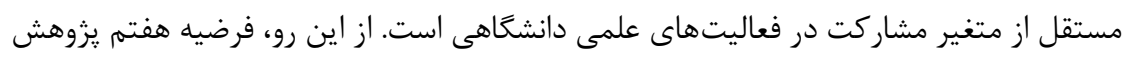

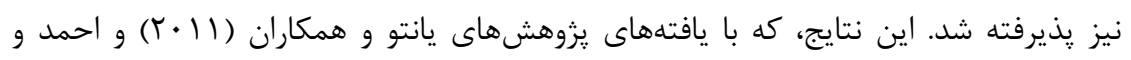

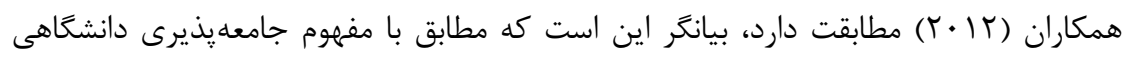

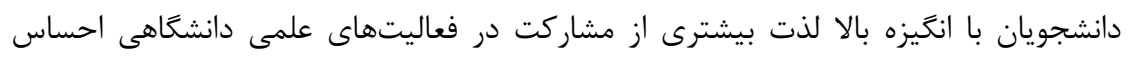

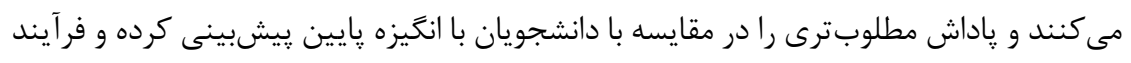

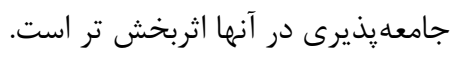

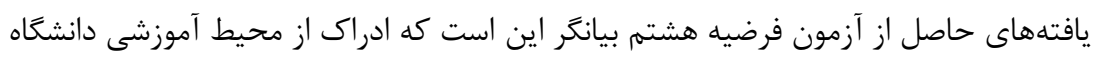

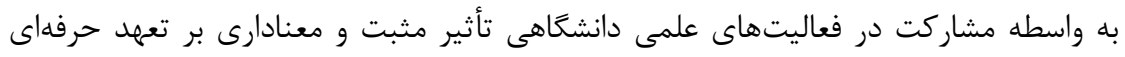

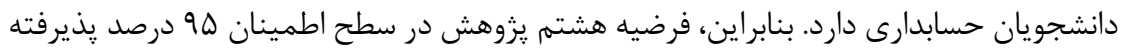

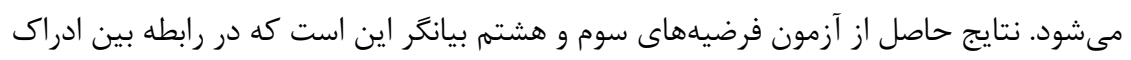

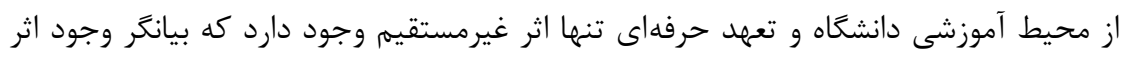

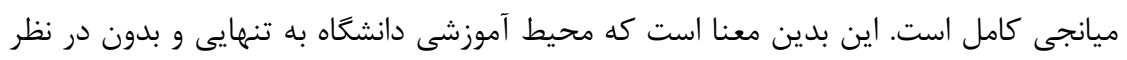

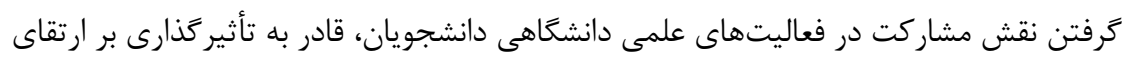
تعهد حرفهاى دانشجويان حسابدارى نمىباشد.

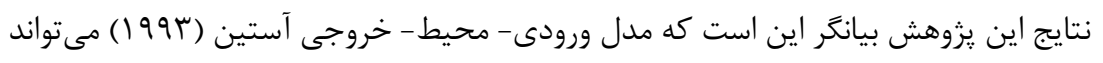

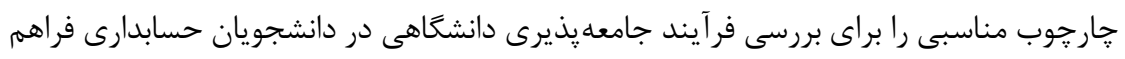

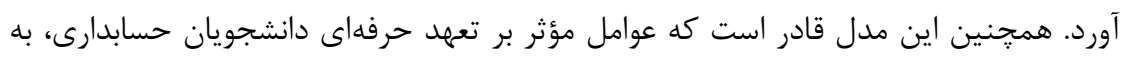

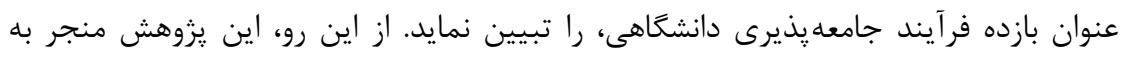

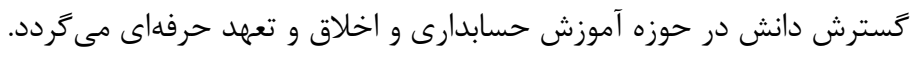


از جنبه كاربردى، نتايج اين يزوهش مى تواند براى دانشكاهها، استادان، تدوين كنندكان خط

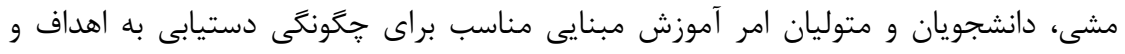

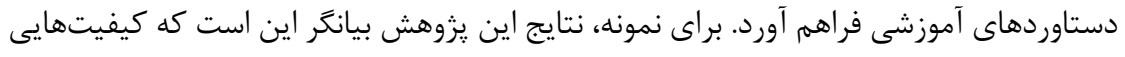

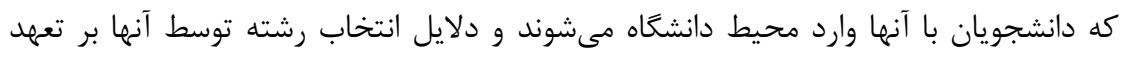

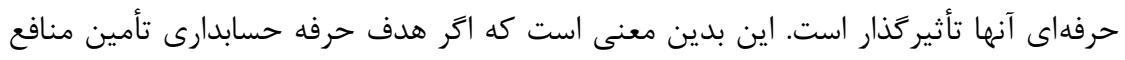

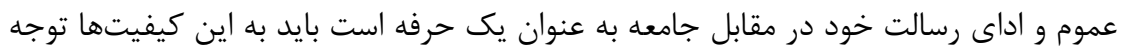

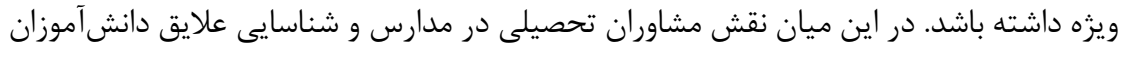

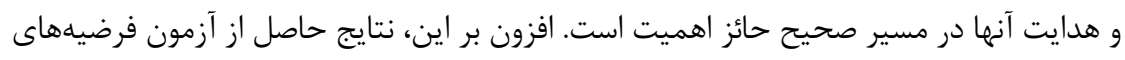

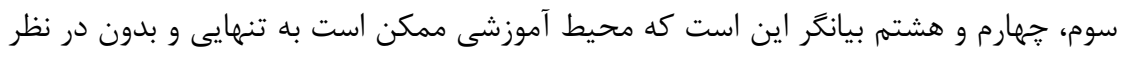

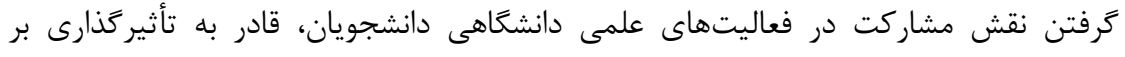

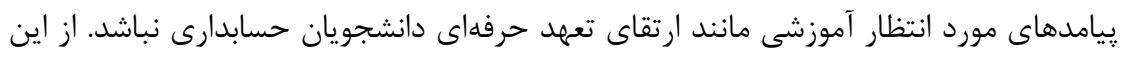

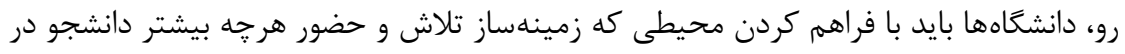

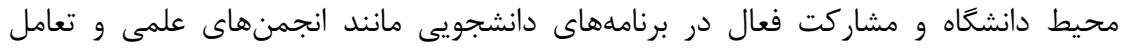

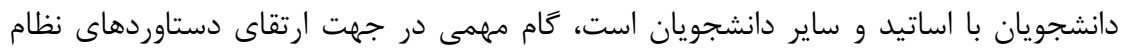

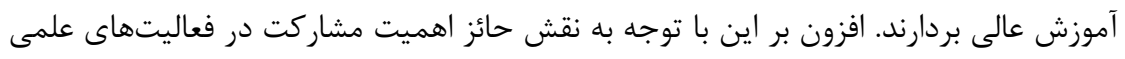

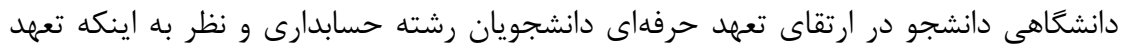

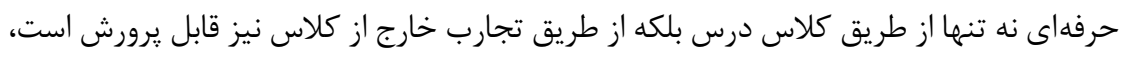

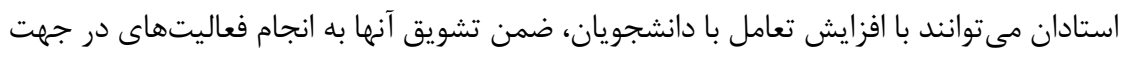

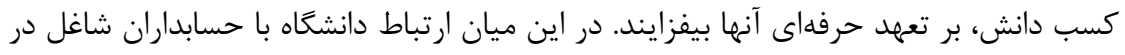

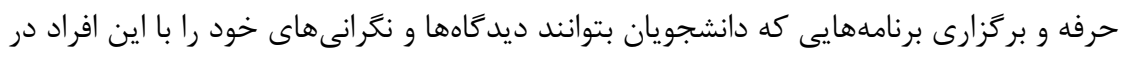

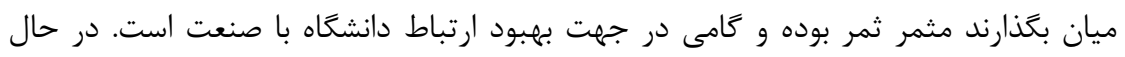

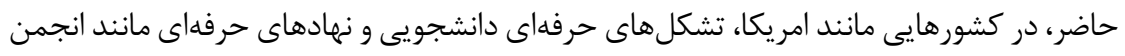

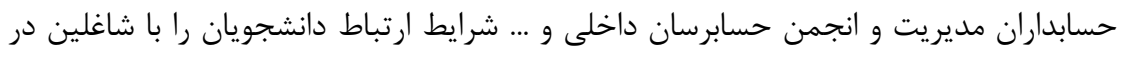

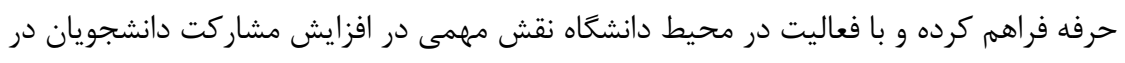

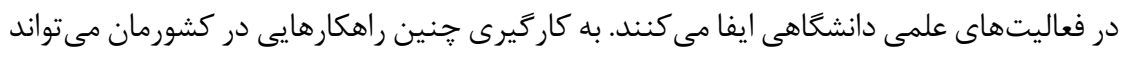

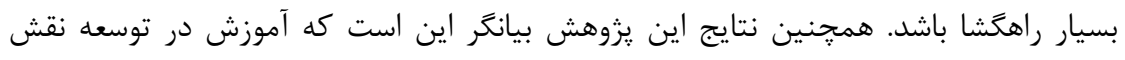

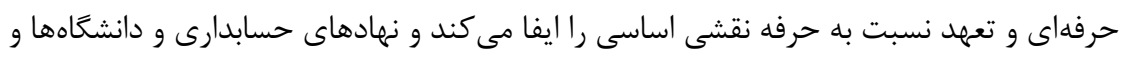

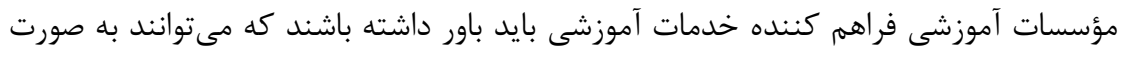

$$
\text { هدفمند در توسعه ارزشهاى حرفه نقشى آفرينى كنند. }
$$


در نهايت، به يزوهشكران آتى پِيشنهاد مى شود كه به بررسى كاركردهايى كه جامعليذيرى

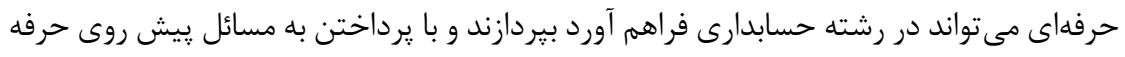

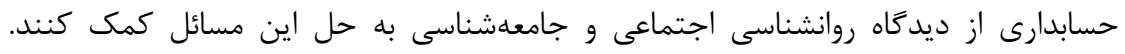

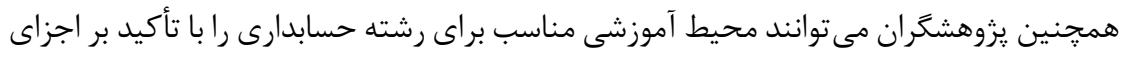

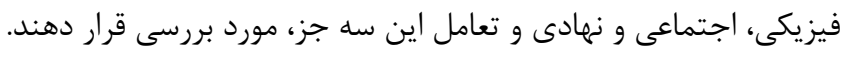

V - Vقدير، تشكر و ملاحظات اخلاقى

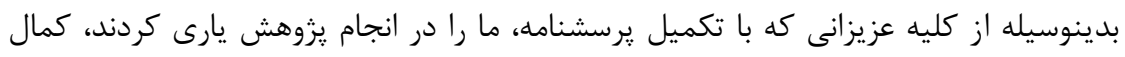

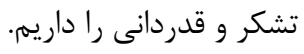

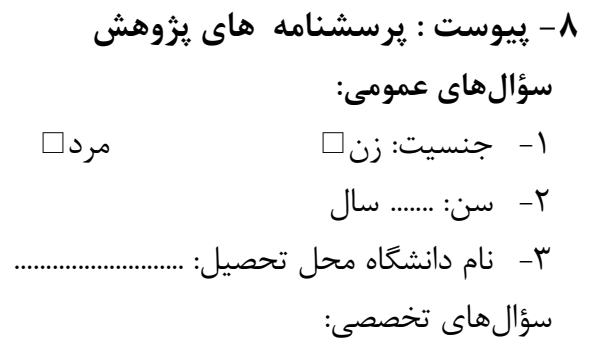

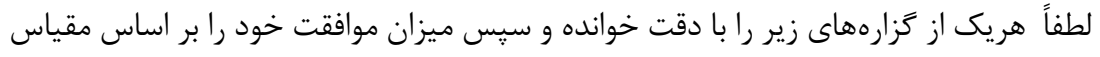

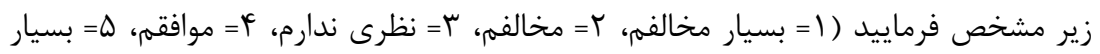

$$
\text { موافقم) }
$$

$$
\begin{aligned}
& \text { " ير سشنامه انغيزه } \\
& \text { 1. من رشته حسابدارى را انتخاب كردم زيرا مباحث حسابدارى را دوست داشته. }
\end{aligned}
$$

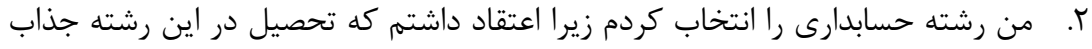
است.

r. من رشته حسابدارى را انتخاب كردم زيرا اعتقاد داشتم كه كرفتن مدرك فرصتهاى

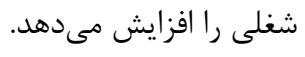

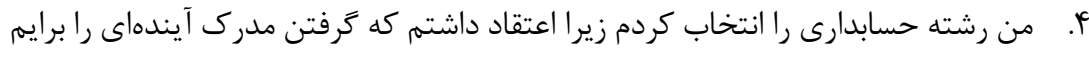
رقم مىزند كه از لحاظ مالى مشكلى نداشته باشئم.

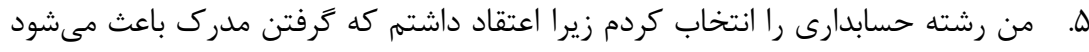
كه يك كار در حوزه حسابدارى داشته باشم. رابن. 


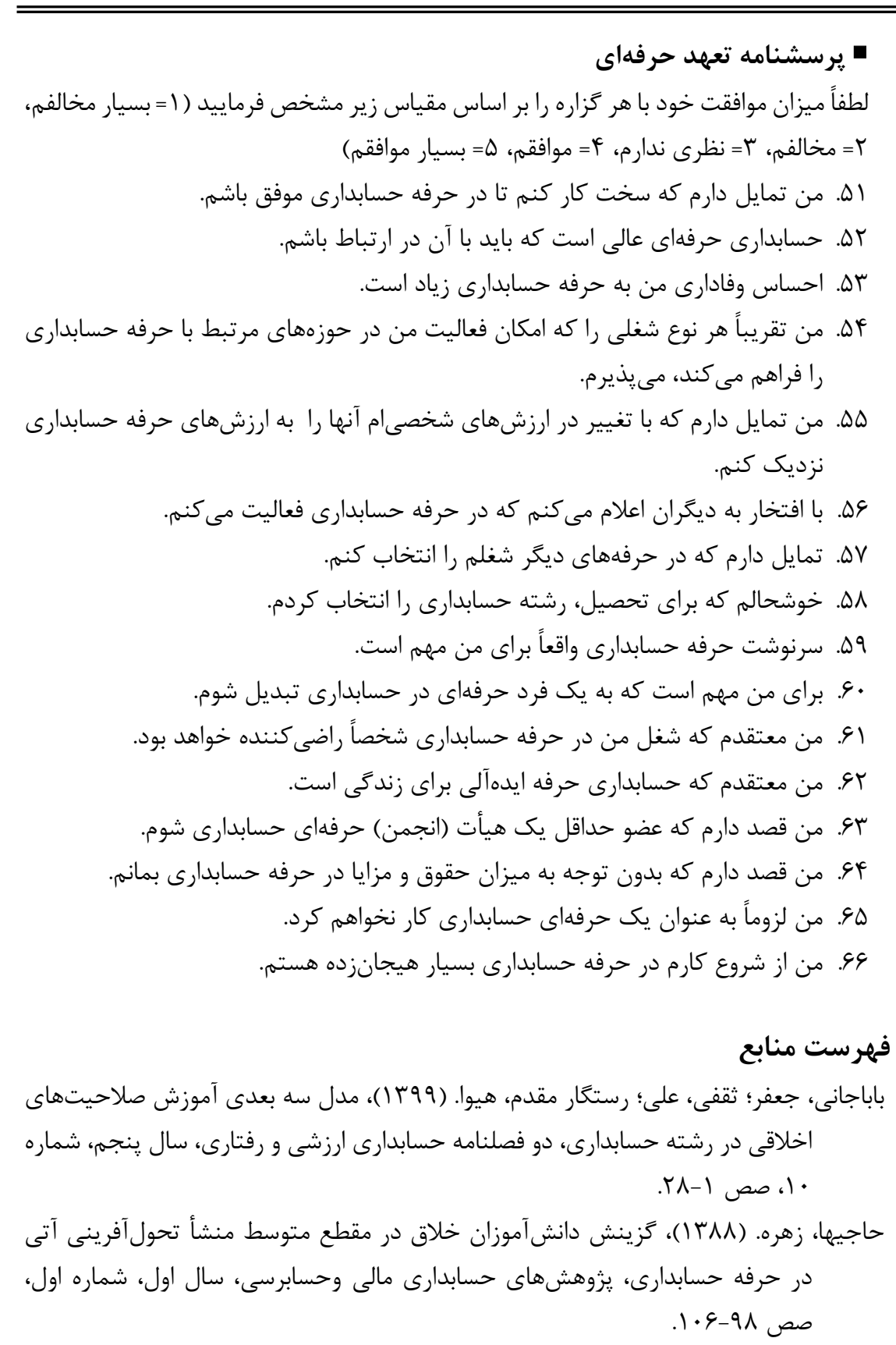


$r+r$ دكتر ابراهيمى و همكاران، بررسى عوامل مؤثر بر تعهد حرفهاى دانشجويان حسابدارى با ...

حميدىزاده، محمدمهدى؛ اوحدى، فريدون؛ شكرى، اعظه. (1)99)، تأثير محيط يادگيرى،

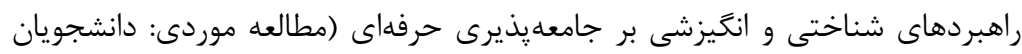

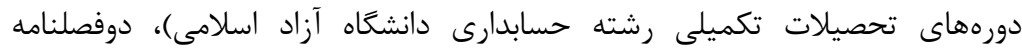

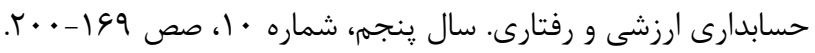

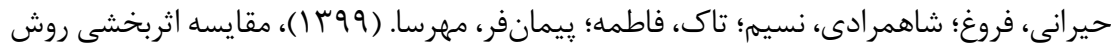

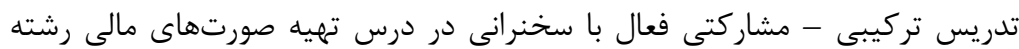

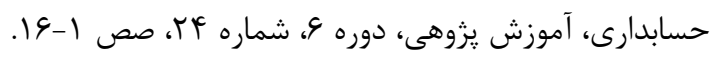

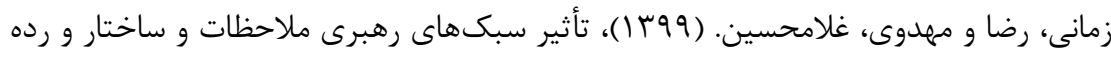

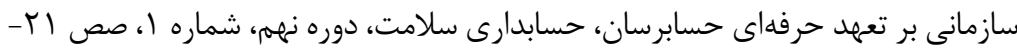

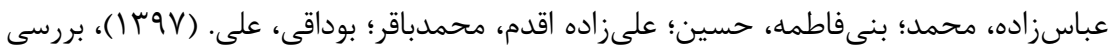

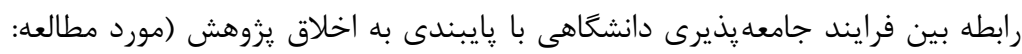
دانشجويان تحصيلات تكميلى دانشخاه تبريز)، جامعهشناسى كاربردى، دوره 9 جا، شماره

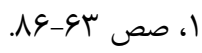

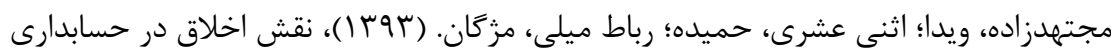

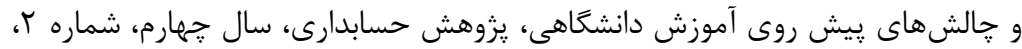

$$
\text { صص }
$$

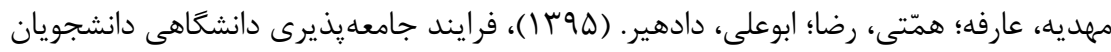

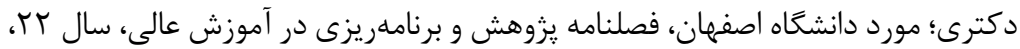

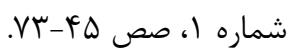

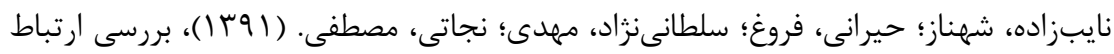

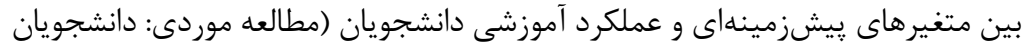

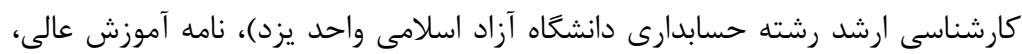

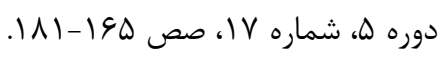

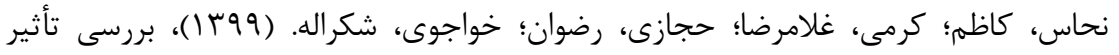

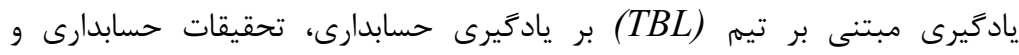

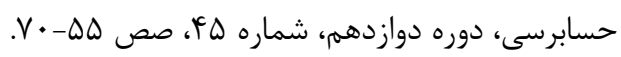

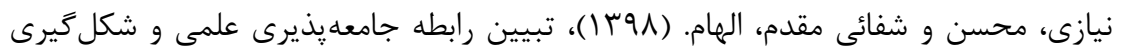

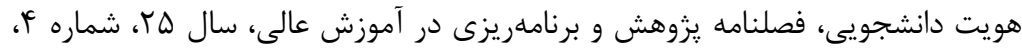


Ahmad, Z., R. Anantharaman, and H. Ismail. 2012. Students' Motivation, perceived environment and professional commitment: An application of Astin's college impact model. Accounting Education 21 (2): 187208.

Alrizqi, D. G., F. I. Ibad, and M. Feriady. 2021. The impact of student engagement towards computer accounting competence of accounting education student in Indonesia. In International Conference on Strategic Issues of Economics, Business and, Education, 67-70, Atlantis Press.

Aranya, N., J. Pollock, and J. Amernic. 1981. An examination of professional commitment in public accounting. Accounting, Organizations and Society 6 (4): 271-280.

Ardts, J., P. Janse, and M. Van der Velde. 2001. The breaking in of new employees: effectiveness of socialization tactics and personnel instruments. The Journal of Management Development 20 (2): 159167.

Astin, A. W. 1984. Student involvement: A developmental theory for higher education. Journal of College Student Personnel 25 (4): 297-308.

Astin, A. W. 1993. Assessment for excellence: The philosophy and practice of assessment and evaluation in higher education. Phoenix, AZ. Oryx.

Baker, R., and S. Wick. 2020. Undergraduate accounting students' perception of a course in accounting research and theory. Accounting Research Journal 33 (1): 217-233.

Bertalanffy, L. V. 1968. General Systems Theory: Foundations, Development, Applications (New York: George Braziller, INC): 32.

Biggs, J. B. 1989. Approaches to the enhancement of tertiary teaching. Higher Education Research and Development 8 (1): 7-25.

Christensen, A. L., and A. M. Woodland. 2016. Is participation in the volunteer income tax assistance (VITA) program associated with students' problem-solving skills and professional commitment?. Issues in Accounting Education 31 (1): 71-90.

Cohen, J. 1992. A power primer. Psychological bulletin 112(1): 155-159.

Elias, R. Z. 2007. The relationship between auditing students' anticipatory socialization and their professional commitment. Academy of Educational Leadership Journal 11 (1): 81-90.

Gardner, S. K. 2010. Faculty perspectives on doctoral student socialization in five disciplines. International Journal of Doctoral Studies 5 (2): 40-53.

Geiger, M. A., and E. A. Cooper. 1996. Using expectancy theory to assess student motivation. Issues in Accounting Education 11: 113-130.

Hair, J. F., G. T. M. Hult, C. Ringle, and M. Sarstedt. 2017. A primer on partial least squares structural equation modeling (PLS-SEM). Sage publications. 


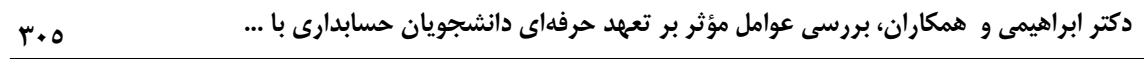

Harwati, D. S., and P. M. P. Heri Yanto. 2017. Vocational high school students accounting competence prediction model by using ASTIN EO model. Dinamika Pendidikan 12 (2): 98-113.

Lee, K., J. J. Carswell, and N. J. Allen. 2000. A meta-analytic review of occupational commitment: Relations with person and work-related variables. Journal of Applied Psychology 85 (5): 799-811.

Leong, L., S. Y. Huang, and J. Hsu. 2003. An empirical study on professional commitment, organizational commitment and job involvement in Canadian accounting firms. Journal of American Academy of Business 2 (2): 360-370.

Linnenbrink, E. A., and P. R. Pintrich. 2003. The role of self-efficacy beliefs in student engagement and learning in the classroom. Reading \&Writing Quarterly 19 (2): 119-137.

Li, W., Wright, P., Rukavina, P. and M. Pickering. 2008. Measuring students' perceptions of personal and social responsibility and the relationship to intrinsic motivation in urban physical education. Journal of Teaching in Physical Education 27(2): 167-178.

Lui, S. S., H. Ngo, and A. W. Tsang. 2001. Interrole conflict as a predictor of job satisfaction and propensity to leave: a study of professional accountants. Journal of Managerial Psychology 16 (5): 469-484.

Pike, G. R., G. D., Kuh, and R. M. Gonyea. 2003. The relationship between institutional mission and students' involvement and educational outcomes. Research in Higher Education 44 (2): 241-261.

Porter, L. W., R. M. Steers, R. T. Mowday and P. V. Boulian. 1974. Organizational commitment, job satisfaction, and turnover among psychiatric technicians. Journal of Applied Psychology 59 (5): 603609.

Rowell, L., and E. Hong 2013. Academic motivation: Concepts, strategies, and counseling approaches. Professional School Counseling 16 (3), 2156759X1701600301.

Weight, W. 1977. An empirical study of the professional socialization of accounting students. International Journal of Accounting 13 (1): 5377.

Yanto, H., J. M. Mula, and M. H. Kavanagh. 2011. Developing student's accounting competencies using Astin's IEO model: An identification of key educational inputs based on Indonesian student perspectives. In Proceedings of the RMIT Accounting Educators' Conference, 2011: Accounting Education or Educating Accountants? University of Southern Queensland. 